Portland State University

PDXScholar

5-4-1999

\title{
The Universal Nature of Hatred: Keith Stimely and the Culture of Holocaust Denial
}

Linda Maizels

Portland State University

Follow this and additional works at: https://pdxscholar.library.pdx.edu/open_access_etds

Part of the Holocaust and Genocide Studies Commons, and the Political History Commons Let us know how access to this document benefits you.

\section{Recommended Citation}

Maizels, Linda, "The Universal Nature of Hatred: Keith Stimely and the Culture of Holocaust Denial" (1999). Dissertations and Theses. Paper 5836.

https://doi.org/10.15760/etd.7707

This Thesis is brought to you for free and open access. It has been accepted for inclusion in Dissertations and Theses by an authorized administrator of PDXScholar. Please contact us if we can make this document more accessible: pdxscholar@pdx.edu. 


\section{THESIS APPROVAL}

The abstract and thesis of Linda Maizels for the Master of Arts in History were presented May 4, 1999, and accepted by the thesis committee and the department.

COMMITTEE APPROVALS:

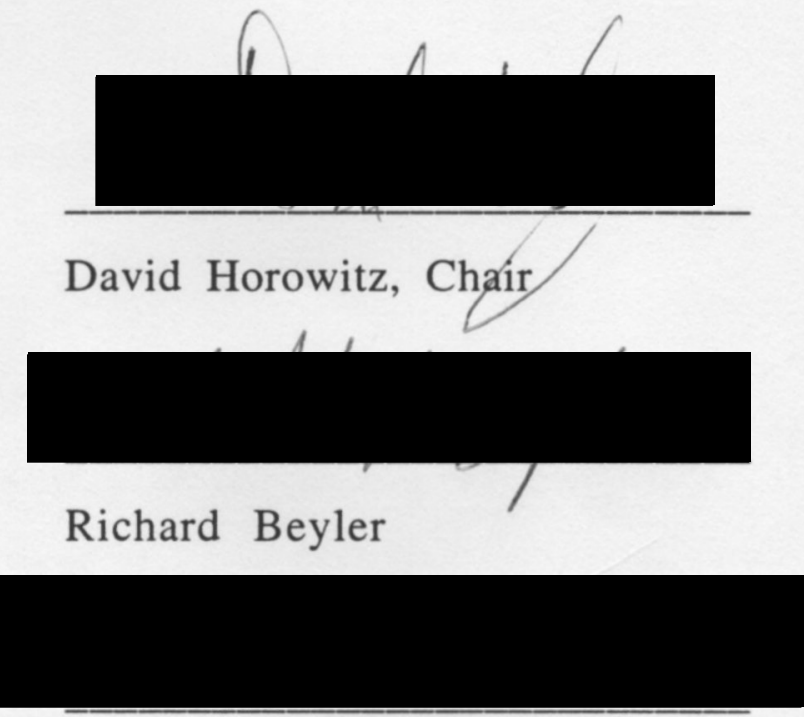

Petyr Beck

DEPARTMENT APPROVAL:

Gordon Dodds, Chair

Department of History

Steven Fuller

Representative of the Office of Graduate Studies

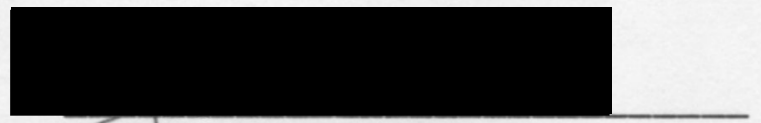




\section{ABSTRACT}

An abstract of the thesis of Linda Maizels for the Master of Arts in History presented May 4, 1999.

Title: The Universal Nature of Hatred: Keith Stimely and the Culture of Holocaust Denial

A partial accounting of the discord beneath the seeming conformity of opinion within the insular community of the proponents of Holocaust denial was documented and preserved by Keith Stimely, a Holocaust denier who donated his personal papers to the University of Oregon Special Collections Library in 1991. The thesis uses the Stimely Collection to emphasize the universal nature of the hatred and animosity inherent in the denial movement.

Chapter One surveys revisionist historiography concerning both world wars and the manner in which the deniers appropriated the trappings of revisionism in their attempt to rewrite the history of the Nazi genocide and create a denial culture. This segment concentrates on denial and its American precursors and contains a brief history of the Institute for Historical Review (IHR), the primary institution associated with Holocaust denial in the United States.

Chapter Two examines Stimely's life before and during his brief tenure as the editor of the Journal of Historical Review, the 
periodical associated with the IHR. Using the personal correspondence from the Stimely Collection, the quest for academic legitimacy within denial culture is considered, as are the rifts that occurred within this insular circle when threats to the possibility of scholarly recognition were identified.

Chapter Three discusses the aftermath of Stimely's departure from the Institute, including his life in Portland, Oregon, and the subsequent gift of his papers to the University. The conclusion hypothesizes that Stimely assembled the Collection in order to posthumously vindicate and promote his views over those of his former colleagues within the culture of Holocaust denial. The more probable legacy of the Collection, though, is that the competing contentions that split the denial movement will be viewed by those who read the documents as equally absurd.

These schisms within the denial community also give credence to the universal nature of the hatred intrinsic to the culture of Holocaust denial. Though many of the deniers begin by targeting their animosity at outsiders, such as Jews, homosexuals and people of color, some of them eventually direct their ire toward colleagues within the movement or, eventually, turn their feelings of hatred inward toward themselves. 
THE UNIVERSAL NATURE OF HATRED:

KEITH STIMELY AND THE CULTURE OF HOLOCAUST DENIAL

by

LINDA MAIZELS

A thesis submitted in partial fulfillment of the requirements for the degree of

\section{MASTER OF ARTS}

in

HISTORY

Portland State University

1999 
This thesis is dedicated to the memory of my best friend and companion, Scruffy Ann (Louise) Maizels, who died on November

19, 1998, after sixteen and a half years of doggy life. May you have a whole piece of toast with peanut butter on it all to yourself every single morning for the rest of eternity. 
Table of Contents

CHAPTER

PAGE

Introduction

I Revisionist Historiography and the Making of Denial Culture

I I Keith Stimely and the Institute For Historical Review

III Life After the IHR

Conclusion

Epilogue

85

Works Cited 


\section{Introduction}

The first stirrings of Holocaust denial began immediately after the end of World War II. Those who denied the event were cautious at first, attempting to relativize or minimize rather than completely negate the devastating aftermath of the Third Reich's murder of the European Jews. However, they became increasingly more bold as the memory of the war faded into the recorded history of a distant event, and the amount of material dedicated to Holocaust denial expanded rapidly.

According to the deniers, the Holocaust, defined as the intention of the German government under the direction of Adolf Hitler to carry out the genocide of the Jews of Europe, was a giant swindle, often referred to as a "Holohoax." While authors such as Arthur Butz, who penned the classic denial text, The Hoax of the Twentieth Century, conceded that many Jews died in a horrible fashion during World War II, they insisted that there had been no special or unique policies of mass murder directed by the German government specifically at the Jews. Any allegation that Jews had been singled out for special treatment had been fabricated and disseminated by "the Zionists," who used stories of atrocities to convince the world to allow the state of Israel to come into being. Israel, then, was an illegally conceived and immoral state that bled 
reparations money from West Germany, stole tax dollars from the American people and oppressed the native Palestinians. ${ }^{1}$

Most deniers identified with right-wing views and were strident anti-Communists who preferred to emphasize the horrors of Stalinism over that of Nazism, or that of the gulag over the extermination camp. By portraying communism as a largely Jewish phenomenon, some denial literature forged a link with traditional antisemitic themes. As one denier, identified as "an unemployed High School History teacher," explained in a letter:

From the opening day of the Great Patriotic War, the absolute scum of the U.S.S.R. found refuge from combat duty at the Gulags. When certain of victory in ' 44 these vermin left the Gulags 'en mass [sic] and poured into the rear lines of the Advancing Red Army. Very many of these scum were jews [sic] who... raped and pilliaged [sic] Eastern Europe with relish... In order to justify their crimes and to distract western investigations these rats began to dehumanize the Germans with the Death Camp Tales... This theory I belive [sic] begins to answer many of the whys of Holocaust mania... How better to disprove the Nazi theory that Communism is jewish [sic] than to have all

\footnotetext{
${ }^{1}$ These opinions can be found in almost any Holocaust denial publication. Arthur Butz's The Hoax of the Twentieth Century is one of the best sources for a complete telling of the deniers' main arguments. In addition, articles from the Journal of Historical Review are useful in ascertaining the views of the deniers.
} 
the European jews [sic] dead and yet still have thriving Communism? $?^{2}$

Yet Holocaust denial has been neither a neo-Nazi nor even solely a right-wing phenomenon. Pierre Vidal-Naquet and Alain Finkielkraut, both of whom have written extensively on the phenomenon of Holocaust denial, have gone to great pains to emphasize the uneasy alliance forged through denial by the radical left and the far-right in France. Finkielkraut has concluded that, within the leftist movement, "there still exists the tendency to try to rewrite Jewish history in function of the antipathy inspired by Israel"3 Hostility from the left, combined with the belief in worldwide conspiracy on the right, has found synthesis within Holocaust denial.

Since the mid-1970s, a growing body of scholarly literature has refuted the claims of the deniers. These authors have sought to explain the phenomenon of Holocaust denial and chart its historical roots while exploring the antisemitic character of its rhetoric. The charge of antisemitism was of paramount importance because the deniers often disavowed any antisemitic intent in their work and portrayed themselves as objective, neutral parties in search of historical truth. Analyses of Holocaust denial frequently contained the additional warning that denial was only

\footnotetext{
${ }^{2}$ Michael J. Kelly to the Institute for Historical Review, 14 December 1983, Box 2, folder 5, Keith Stimely Collection, University of Oregon Special Collections Library, \#183.

${ }^{3}$ Alain Finkielkraut, The Future of a Negation: Reflections on the Question of Genocide, trans. Mary Byrd Kelly (Lincoln: University of Nebraska Press, 1998), 96.
} 
the first step toward a hatred and bigotry that had universal application beyond the problem of antisemitism. ${ }^{4}$

While scholars in the field used the terms "Holocaust denial" and "Holocaust deniers," those who refused to accept the Holocaust as an actual historical event preferred to label themselves as "revisionists." The deniers appropriated this title from American historians like Charles A. Beard who were disturbed by the involvement of the United States in World War I and wanted to discredit the notion that Germany was solely responsible for the conflict; their literary efforts focused on shifting the mantle of blame so that it rested equally on Allied shoulders. In attempting to appear as the heirs to the historical tradition of revisionism, the deniers sought to legitimate themselves by proposing an ongoing academic debate challenging the veracity of the Holocaust. Deniers even went so far as to label historians who opposed their views as "exterminationists" in order to substantiate the notion of two schools of thought on the subject. Their quest for intellectual legitimacy was quashed, however, when academics characterized their literary efforts as "psuedoscholarly" and refused to engage in debate for fear of encouraging any idea that Holocaust denial was an historically-based, factually plausible explanation of past events. Refutations of Holocaust denial were disseminated through

\footnotetext{
${ }^{4}$ Both Deborah Lipstadt's Denying the Holocaust: The Growing Assault on Truth and Memory and Kenneth Stern's Holocaust Denial make this argument.
} 
lectures, books and articles in scholarly publications but not through open discourse with the deniers. ${ }^{5}$

Because the deniers have faced opposition from a majority of the academic community, an insular denial culture has developed. Despite the desire to portray themselves as an embattled yet cohesive minority, however, numerous splits and schisms have prevented them from presenting a unified front with which to counter the historical establishment. A partial accounting of some of the discord beneath the seeming conformity of opinion within the denial coterie was documented and preserved by Keith Stimely, a Holocaust denier who donated his collection of personal papers to the University of Oregon in 1991. This thesis uses the Stimely Collection to make a comparison between the deniers' published literature, which disavows any antisemitic intent, and their private correspondence, which especially targets Jews but also indicts homosexuals and people of color. These personal letters also suggest that some of the animosity of various deniers is directed toward individuals from within their own ranks. This intragroup hostility can be traced to a genuine anxiety about individuals who are perceived to hinder the eventual acceptance of the cause within academia. However, there is also an indication that the deniers exhibit a fundamental inability to maintain functional and lasting interpersonal relationships. The letters

\footnotetext{
${ }^{5}$ Again, the best sources that respond to the arguments of the deniers are the books by Stern and Lipstadt. The annotated bibliography included at the end of this paper gives detailed information on additional sources.
} 
indicate that, beleaguered by perceived threats from outside the group and suspicious of their colleagues, some of the individuals within the culture eventually turn away from the group that shares their worldview or band together to shun a previously valued member of the community. A few even show signs of turning their feelings of hatred and animosity inward toward themselves.

Chapter One surveys revisionist historiography concerning both world wars and the manner in which the deniers appropriated the trappings of revisionism in their attempt to rewrite the history of the Nazi genocide and create a denial culture. This survey will concentrate on denial and its American precursors and will also contain a brief history of the Institute for Historical Review (IHR), the primary institution associated with Holocaust denial in the United States.

Chapter Two examines Stimely's life before and during his brief tenure as the editor of the Journal of Historical Review, the periodical associated with the IHR. Using the personal correspondence from the Stimely Collection, the quest for academic legitimacy within denial culture will be considered, as will the rifts that occurred within this insular circle when threats to the possibility of scholarly recognition were identified.

Chapter Three discusses the aftermath of Stimely's departure from the Institute, including his life in Portland, Oregon and the subsequent gift of his papers to the University. The conclusion to 
this work offers a hypothesis as to the lasting impact or legacy of Stimely's collection, including a speculative look at the reasons behind the donation and the implications of the hatred that is an intrinsic part of the denial movement. An epilogue brings the history of the IHR up to date 
Chapter I: Revisionist Historiography and the Making of Denial Culture

The quest for academic legitimacy within denial culture in the United States began with the attempt to appropriate the revisionist title from a controversial historical school that appeared after World War I. In an attempt to decrease the burden of responsibility placed on Germany after the war, the historical reevaluation offered by these revisionist scholars emphasized the equivalent culpability of the Allied nations and denounced the Versailles treaty as an unfair and vindictive document. While the historical works produced by Sidney B. Fay, Charles S. Beard and others were not overwhelmingly popular, the literature won respect because it was historically sound and factually based. In contrast, revisionist attempts to rework the history of World War II were not as widely accepted by the academic community. A.J.P. Taylor's The Origins of the Second World War argued that both sides in the conflict had made diplomatic blunders that created the eventual conflict. Although Taylor was careful to point to Hitler's atrocities, critics attacked the British historian for the "conceptual perversity" and "methodological flaws," that marred his book, arguing that it substantiated the claims of Nazi apologists. ${ }^{6}$ Charles C. Tansill's Back Door to War also provided a foundation for future deniers by arguing that the British and the Americans had pushed

${ }^{6}$ Lucy S. Dawidowicz, Lies About the Holocaust, ed. Neal Kozodoy, What is the Use of Jewish History? (New York: Schocken Books, 1992), 85. 
Poland into behaving aggressively toward Germany, thus forcing the Germans to retaliate with force and triggering the start of the War. ${ }^{7}$

The arguments used in the historical revision of both wars were later used to support the perspective of Holocaust deniers. Three examples of connections between the deniers and earlier revisionists support this conclusion. First, many revisionists of the first war revealed that the British and Americans had circulated false stories of atrocities to encourage their citizens to support the war effort. The deniers later followed this by asserting that, if the bayoneted Belgian babies of the first war had been invented by propagandists, why should the Jewish children led to gas chambers during the second be any more plausible? Second, in the aftermath of both wars, some of the revisionist literature relativized German war crimes by stressing the atrocities committed by the Allied Powers and equating Britain's imperialistic designs with Germany's dreams of eastward expansion. While Allied abuses such as the bombing of Dresden were, unfortunately, true, the deniers used these incidents to lessen the implications of the uniqueness of German war crimes. ${ }^{8}$ Third, the revisionists supported the perception, popular with noninterventionists before and during both wars, that

\footnotetext{
${ }^{7}$ Deborah Lipstadt, Denying the Holocaust: The Growing Assault on Truth and Memory (New York: The Free Press, 1993), 40.

${ }^{8}$ Both Lucy Dawidowicz's essay and Deborah Lipstadt's book supply information on the connection between the deniers and the early revisionists.
} 
international financiers and bankers, often linked to Jewish interests, had forced America into war in order to amass huge profits. Senator Robert M. LaFollette's statement in 1919 echoed the view of some isolationists of the time;"[J.P.] Morgan and the group of Jew bankers expect to 'finance' the war settlements and rake down commissions." 9 Similarly, before Pearl Harbor, Charles Lindbergh reported to the non-interventionist America First Committee that "the three most important groups who have been pressing this country toward war are the British, the Jewish and the Roosevelt administration."10 Additionally, American presidents during both wars were portrayed by revisionists as eager for intervention in what were seen as purely European conflicts. President Wilson was characterized as beholden to banking and the munitions industry, while Roosevelt was accused more specifically of being held hostage to Jewish concerns. The deniers used these claims to bolster their own allegations about Roosevelt, namely that his entanglement with the Jewish community had led him to dupe the nation into entering the war against Hitler through the orchestrated catastrophe at Pearl Harbor. This accusation has remained popular with deniers, including one man who wrote to the Journal of Historical Review to protest against an article which stated that FDR might not have been unduly influenced by Jews. The correspondent, who

\footnotetext{
9 David A. Horowitz, Beyond Left and Right: Insurgency and the Establishment (Chicago: University of Illinois Press, 1997), 36.

${ }^{10}$ Ibid., 182.
} 
identified himself as a retired Lieutenant Colonel in the United States Air Force, insisted that the president had been "a 1/8 Jew himself, surrounded by more Jews than any previous president, sainted by Jews, speeches written for him by Jews." ${ }^{11}$

The most direct link between American revisionists and the Holocaust deniers was Harry Elmer Barnes, an American historian, sociologist and journalist. A respected, if controversial, historian at the time when he published revisionist works on World War I, Barnes lost credibility in the academic community when he proceeded to defend German conduct both before and during the second war. In The Struggle Against the Historical Blackout, which was published in 1947 and was the first of his forays into conspiracy theory, Barnes accused Allied governments and their court historians of wrongfully assigning blame to Germany for starting the war and then fabricating or exaggerating instances of German atrocities. Revisionist historians like himself, Barnes claimed, were denied access to documents concerning the conflict and subjected to a concentrated smear campaign as part of the perpetuation of a worldwide historical blackout. ${ }^{12}$

Barnes then took the next step toward full-fledged denial of the extermination of the European Jews. Influenced by various French authors like Paul Rassinier, a survivor of the concentration camps Buchenwald and Dora who went on to deny the Holocaust,

\footnotetext{
${ }^{11}$ Walter (name obscured) to the Institute for Historical Review, 20 October 1983, Box 2, folder 3, Keith Stimely Collection, University of Oregon Special Collections Library, \#183.

${ }^{12}$ Lipstadt, Denying the Holocaust. 69.
} 
Barnes was now ready to declare the mass murder of the Jews to be an exaggeration promulgated solely to assist in vilifying the Germans and justifying the Allies, thus making the Allies the real scoundrels in this catastrophic and unnecessary war. While reluctant to actually deny the Holocaust, Barnes published two articles in the mid-1960s that characterized information on the attempted genocide as exaggerated and unproved and insisted that Allied atrocities had been much worse than anything perpetrated by the Germans. ${ }^{13}$

At roughly the same time as Barnes, Austin J. App, an American professor of English literature, began to express publicly his theories and views about the Holocaust through a letter-writing campaign directed at major periodicals and public figures. The son of German immigrants, App was much more unrestrained in his critique of American and British policy and much more forthcoming in his denial of the Holocaust than Barnes. Eschewing Barnes' euphemisms, he began by ignoring the gas chambers in his writings and later claimed that they were merely a hoax used to fool an unwitting public. ${ }^{14}$

In 1973, App published The Six Million Swindle:

Blackmailing the German People for Hard Marks with Fabricated Corpses. This pamphlet formulated eight assertions that continue to serve as the foundation of Holocaust denial literature. The main idea behind these assertions was to exonerate the Nazis by

\footnotetext{
13 "Ibid., 74-76..

14 Ibid., 87.
} 
claiming that neither they nor Hitler had any special plan to annihilate the Jews, that any Jews who died during the war did so for legitimate and justifiable reasons and, last, that Israeli and Jewish leaders were responsible for the creation of the Holocaust hoax..$^{15}$

The pamphlet firmly linked App's denial arguments with more traditional antisemitic themes. While many former noninterventionists, German sympathizers and others who engaged in revisionist or quasi-denial history were staunch antiCommunists who felt that Stalin, not Hitler, was the true villain of the twentieth century, App's conspiracy theory inextricably tied the Jews to the Communists and proclaimed them the authors of the swindle. App also attacked Zionists and the state of Israel and declared that Jewish control of the media led to a more efficient dissemination of the hoax on behalf of the Allied governments. ${ }^{16}$ App's pamphlet was also significant in that it marked the beginning of an entirely new way of presenting antisemitic material. Blatant anti-Jewish hatred was no longer acceptable in American society after the full extent of the Holocaust was revealed to the public. While App's style retained some of the overtly antisemitic content found in neo-Nazi and other publications, his attempts to deny the Holocaust used euphemistic language and mimicked a scholarly writing style. These innovations helped App and others win converts to the cause who

\footnotetext{
15 Ibid., 94-99.

${ }^{16}$ Ibid., 95-98.
} 
might have felt alienated by more openly antisemitic language. The ultimate expression of this new approach to antisemitism appeared in Arthur Butz's The Hoax of the Twentieth Century. ${ }^{17}$

For Butz, the Holocaust was a Zionist hoax that had hoodwinked the nation-states and people of the world into sympathizing with the Jews and, consequently, rewarding them with their own homeland. Because the Zionists had advanced such a deceitful lie, any material pertaining to the Holocaust, whether it was an account by a Jewish eyewitness or a historical work written by a Jew, was immediately suspect and was to be dismissed. "In the final analysis," Butz wrote, "the difficulty is that the figures available amount to nothing more than statements, from Jewish and Communist sources, that millions of Jews were killed." ${ }^{18}$ Although his book was filled with references to "the ubiquitous Zionist International," Butz assured his readers that

The word 'Zionist' is not being employed here as a code word for 'Jewish'; the evidence shows that, while the hoax is certainly a Jewish hoax, in the sense of having been invented by Jews, it is also a Zionist hoax, in the sense of having been invented by Jews who were Zionists on behalf of Zionist ends. ${ }^{19}$

Butz's position as a tenured professor of electrical engineering at Northwestern University only enhanced the appeal

7 Ibid., 124.

${ }^{18}$ Arthur A. Butz, The Hoax of the Twentieth Century (Richmond, Surrey: Historical Review Press, 1974), 17.

${ }^{19}$ Ibid., 87. 
of his book for the deniers. His scientific and scholarly (if ponderous) style seemed to adhere scrupulously to the requirements and standards of academic research, yet scholars attacked his work for its manipulation of existing source material, deliberate falsification of data, penchant for misquoting or quoting out of context and shallow reading of texts. ${ }^{20}$

Butz's book was originally published in England and did not find American support until 1977, when the Noontide Press acquired the rights to his book. This new connection was notable because Noontide was tied to Willis Carto, the man the AntiDefamation League has described as "the most important and powerful professional antisemite in the United States." ${ }^{21}$ Carto's Liberty Lobby, founded in 1958, as well as the organization's publications (a newsletter and weekly newspaper, The Spotlight), were well known as vehicles for promulgating racist, antisemitic and anti-Zionist ideology. Because of his proclivity for avoiding the media, however, Carto managed to keep his personal views relatively unpublished. He was much more forthcoming in the few pieces of his private correspondence which have been discovered. In one letter to a colleague, he confided his belief that the Nazis and the Zionists had collaborated before and during the war. $\mathrm{He}$ described this supposition as 'a known fact and a rather

\footnotetext{
${ }^{20}$ These are standard arguments made against the deniers and can be found in Lipstadt, Dawidowicz and Stern. Even more specifically, a good analysis of Butz's work is Jacques Kornberg, "The Paranoid Style: Analysis of a Holocaust-denial Text," Patterns of Prejudice, 1995, Vol. 29, Nos 2 and 3.

${ }^{21}$ Lipstadt, Denying the Holocaust. 145.
} 
suppressed scandal amoung the jew [sic] community... Americans, and I guess Germans, too," he wrote in 1984, are just about convinced that the only people who suffered during the war were jews [sic]; that nothing else happened during that time other than jew extermination; that the history of the world, literally approved by god, is the history of whatever the ruling jews say it is and nothing else. ${ }^{22}$

Perceiving that the Liberty Lobby's reputation for extremism was becoming problematic in the quest to win more followers for the denial cause, Carto created the Institute for Historical Review (IHR) in 1979. The IHR eschewed overt antisemitism in favor of a more scholarly and professionally-oriented style. The organization sponsored conventions where professed Holocaust scholars gathered to present papers, absorbed the Noontide Press as its own publishing arm and released a periodical entitled the Journal of Historical Review. Despite Carto's protests that the IHR was an independent organization with no ties to the Liberty Lobby or any of his other enterprises, all of the organizations tied to Carto were rooted in racist ideology, even if their external trappings differed..$^{23}$

This first director of the IHR was David McCalden, also known as "Lewis Brandon," who was with the Institute from its

\footnotetext{
${ }^{22}$ Willis Carto to Keith Stimely, 17 April 1983, Box 2, folder 1, Keith Stimely Collection.

${ }^{23}$ Anti-Defamation League, Hitler's Apologists: The Anti-Semitic Propaganda of Holocaust "Revisionism" (New York: Anti-Defamation League, 1993), 5.
} 
inception until he left on courteous terms two years later.

Originally from Northern Ireland, McCalden had been a member of the National Front, England's right-wing extremist party which promoted "racial nationalism," before he emigrated to the United States. ${ }^{24}$ During his tenure, the organization sponsored its first Revisionist Convention in 1979, which, at first, garnered little publicity. This changed when McCalden announced that the IHR was willing to pay $\$ 50,000$ to anyone able to prove the existence of Nazi gas chambers. The offer was mostly ignored until he began sending personal letters to well-known survivors, challenging them to prove the veracity of what they had seen. Despite the advice of various Jewish organizations to disregard the challenge, an Auschwitz survivor from Long Beach, California, Mel Mermelstein, responded. Correspondingly, media coverage of the IHR increased exponentially. Although Mermelstein mailed the IHR a notarized document detailing his experiences during the war, the IHR refused to pay him the reward money. He proceeded to file suit against the IHR, Carto, and McCalden in February of 1981. The proceedings dragged on until the case was settled in July 1985 , when Mermelstein was awarded $\$ 90,000$, which included the $\$ 50,000$ award and $\$ 40,000$ for his pain and suffering. Employees of the IHR were also required to send a letter of apology to the victorious survivor. ${ }^{25}$

\footnotetext{
${ }^{24}$ Anti-Defamation League, Hitler's Apologists, 16.

${ }^{25}$ Lipstadt, Denying the Holocaust. 139-141.
} 
Initially, the staff of the IHR stood staunchly by the decision to issue the challenge. In pre-trial hearings, when Judge Thomas Johnson of the California Superior Court took judicial notice of the fact that Jews were gassed at Auschwitz and that this was not subject to argument, the IHR retorted in its 1981 newsletter that "the court has done the almost inconceivable in setting itself up as the final say on what is, and what is not, history. It has ruled -- as historical fact -- on an issue which has been a matter of controversy among historians for years." 26 Following the judgment against the organization, however, the IHR claimed that the letter McCalden had sent to Mermelstein had been "unauthorized." Worse, it was alleged that McCalden had relayed damaging information to Mermelstein's lawyer through his fiancée, who was reported to be Jewish. "The part McCalden played in Mermelstein's attempt to destroy the Institute is simply incredible," reported the newsletter. ${ }^{27}$ Once a trusted member of the community, McCalden was now an object of derision and scorn. After breaking from the Institute, McCalden began sponsoring the David McCalden Revisionist Newsletter and a new organization called Truth Missions, which denounced the settlement as "a complete CARTO surrender and sell-out." McCalden stressed that he had refused to pay any of the settlement costs and declined to sign any apology. "I am sure," he

\footnotetext{
${ }^{26}$ The IHR Newsletter, October/November 1981, Box 1, folder 2, Keith Stimely Collection.

${ }^{27}$ The IHR Newsletter, August 1985, Box 1, folder 2, Keith Stimely Collection.
} 
propounded to his readers, "you are as aghast as I am at this total surrender; this pathetic sell-out, this cynical betrayal." The remainder of the letter was a plea for financial support because McCalden was convinced that the Mermelstein settlement would finish the IHR and "our only hope is to build up TRUTH MISSIONS: the Provisional Institute for Historical Review into an organization as big as the old IHR was." 28

In the four years since McCalden had left the IHR, his cordial relationship with individuals who worked for the organization had disintegrated. His gradual estrangement from the mainstream of denial culture is an integral part of the period documented by the Stimely Collection. The letters penned by Stimely and others demonstrate the lack of tolerance that members of the IHR had for individuals like McCalden who were seen as capable of jeopardizing the reputation of the group as a whole. Additionally, the letters betray the inability of many of the deniers to maintain functional and lasting interpersonal relationships or to adhere to any code of civility once a relationship soured. Indeed, McCalden's failure to remain on good terms with his former colleagues was not unusual within the community of deniers that converged around the IHR.

\footnotetext{
${ }^{28}$ David McCalden, 23 July 1985, Box 1, folder 4, Keith Stimely Collection.
} 
Chapter II: Keith Stimely and the Institute for Historical Review

In November 1983, Keith Bishop Stimely became the editor of the Journal of Historical Review. Stimely was born in 1957 in Connecticut but was raised mainly on the West Coast. He began his studies at San Jose University but graduated from the University of Oregon in 1980 with a bachelor's degree in history. ${ }^{29}$ A former professor at Oregon recalled that Stimely was "one of the most interesting, engaging, and challenging students $\mathrm{I}$ had at the UO... a bright, troubled young man" with a "passion" for studying the Holocaust. He also remembered that while Stimely was "prepared to concede that many millions of Jews had lost their lives, often to German maltreatment of one sort or another [during World War II]... he insisted that the regime never embraced a comprehensive or systematic policy of extermination." ${ }^{30}$

Stimely received an "A" on an undergraduate paper entitled "Revisionism and the 'Holocaust': An Introductory Examination in the Form of an Essay and a Study Guide," in which he argued that the "'Holocaust' legend" was used to justify not only Israel's existence but also its misdeeds and human rights abuses. However, his main concern was that too much attention was paid

\footnotetext{
${ }^{29}$ Keith Stimely, ed., 1981 Revisionist Bibliography: A Select Bibliography of Revisionist Books Dealing with the Two World Wars and their Aftermaths (Torrance, Calif.: Institute for Historical Review, 1981).

${ }^{30}$ Roger Chickering (chickerr@ibm.net). (1998 August 28). Help with my thesis? E-mail to Linda Maizels (psu14560@odin.cc.pdx.edu).
} 
to the problem of Israel and not enough to the fact that the Holocaust had engendered "the creation of world-wide sympathy for and identification with the Jews generally." Stimely argued that this emphasis on Jewish suffering intimidated non-Jews and prohibited any criticism of Jewish actions. "The sword of the Auschwitz-spectre hangs by a thin thread over the head of anyone discussing the Jews," Stimely warned, and we must be extremely careful not to sound "antisemitic" (whatever that means), for is it not but a step from "anti-semitism" to -- the gas chambers (or, to use the entirely meaningless but deliciously evocative phrase of many of the Holocaust'ers: "gas ovens")? ${ }^{31}$

Stimely's former professor recalled that the student originally had been careful to mask his beliefs with euphemistic language. By the time he was closer to graduation, though, Stimely "made no bones about being a racist, in the sense that he believed that racial differences were the motor of history and that the white race was inherently superior." Through this unmasking of Stimely's convictions, his professor came to the conclusion that his student's "views on the Holocaust have to be placed in this context." 32

\footnotetext{
${ }^{31}$ Keith Stimely, Revisionism and the 'Holocaust': An Introductory Examination in the Form of an Essay and a Study Guide, March 1979, Box 22, folder 1, Keith Stimely Collection, University of Oregon Special Collections Library, \#183.

${ }^{32}$ Roger Chickering (chickerr@ibm.net). (1998 August 28). Help with my thesis? E-mail to Linda Maizels (psu14560@odin.cc.pdx.edu).
} 
Letters written by Stimely show that he began searching for a peer group with which to share his ideas about the Holocaust while he was still in college. In a letter to Angriff Press, a supplier of racist and neo-Nazi literature in Hollywood that advertised "Books for Patriots," Stimely asked,

I am curious -- do you find a great number of people writing in for information and books? I ask this possibly intrusive question only because it often seems to many of us out here with 'our' point of view, that we are virtually alone in hostile and ignorant America. It would certainly be heartening for me to know that there are indeed appreciable others who are disturbed enough and courageous enough to seek the truth. ${ }^{33}$

The growing emphasis on multiculturalism and diversity in the United States, as well as the assertion of ethnic and racial group pride that often coalesces around shared group suffering, may have helped to shape Stimely's lament. Perhaps he was merely looking for a place where, as a white, Christian male, he, too, could find pride and a sense of community. However, the feelings of alienation and persecution that led to his search for a peer group were predicated on his perception that the Holocaust was used as a shield by the Jewish people, proof of their status as the perpetual scapegoat, as "the gold standard of oppression, as the

\footnotetext{
${ }^{33}$ Keith Stimely to Angriff Press, 20 November 1978, Box 30, folder 9, Keith Stimely Collection.
} 
paradigm of the victim." 34 For Stimely, the pernicious nature of the Holocaust myth was that it added to the status of the Jew as victim, even if it was really a manifestation of Jewish power. The strength of Israel and of American Jewry, proof of Jewish hegemony, had to be counterbalanced by a catastrophic event, the Holocaust hoax, in order for the Jews to retain their precious victim status. The real victims were those who were brave enough to challenge this Jewish conspiracy in their quest to advance the truth. As one supporter of the IHR would later write to Stimely, "I commend your... courage, for obviously you're in the frontlines of the battle for Truth [sic], and the international Zionists... seem to be able to operate without hindrance here in the present JEWnited States as in Lebanon." ${ }^{35}$

Stimely's search for those who believed as he did took two forms: one that emphasized the weakness of the world against the connivance of the Jews, and one that took a more racist tone and posited superiority to the Jewish people. In July 1979, Stimely implored Paul Englert, the Secretary of the Confraternity of Deists to, "please understand my enthusiasm in wishing to share information with a fellow hater of Today and a lover of a Tomorrow that we can perhaps help make," and asked,

\footnotetext{
${ }^{34}$ Alain Finkielkraut, The Future of a Negation: Reflections on the Question of Genocide, trans. Mary Byrd Kelly (Lincoln: University of Nebraska Press, 1998), 101.

${ }^{35}$ William Gardiner to Keith Stimely, 3 October 1982, Box 2, folder 4, Keith Stimely Collection.
} 
I am especially interested in finding out what conscientious Deist-thinkers like yourself think about the present Western political imperatives (i.e.: maintaining and safeguarding the White Race; renouncing and eliminating Culture Distortion -- that is, Jews, and especially all the traitor gentile 'Jews' running around; renewing our Western Culture) and how to achieve them, and what role religious-spiritualmystic feeling might have to play in this. ${ }^{36}$

In his quest for fellowship, Stimely also applied for membership in Äsatrüaratal, a register of those "true to the pagan gods of the North." He listed as his "Special Interests Within Odinism" the subjects "Atlanteology," "Aryan history and prehistory," "'Positive' or 'Nordic' Christianity," and "Mysticism and the Occult" He was quick to note, though, that his interest in the occult was "more curiosity here than anything else." Other interests listed by Stimely included "Francis Parker Yockey," "Revisionist History of World War II," "Cyclical theories (a la Spengler, Yockey, de Riencourt, etc.) of History and Western decline," and "Prospective concrete-political applications of the ImperativeIdea." ${ }^{37}$

Like his interest in matters relating to the Holocaust, Stimely's fascination with Francis Parker Yockey is a recurring

\footnotetext{
${ }^{36}$ Keith Stimely to Paul Englert, 8 July 1979, Box 34 , folder 8, Keith Stimely Collection.

${ }^{37}$ Keith Stimely, Application for membership in Äsatrüaratal, Box 31, folder 8, Keith Stimely Collection.
} 
theme in his personal papers. Yockey was primarily known for writing Imperium -- The Philosophy of History and Politics, which prophesied that the ideal form of government would prove to be an imperium, a universal imperialism comprised of Western Aryan nations that would follow the National Socialist model of government. Dedicated to Adolf Hitler, the book mimicked Nazi ideology by claiming that the enemies of imperium were the Jews, the only group capable of destroying this utopian civilization. Previous to writing Imperium, Yockey was discharged from the U.S. army in 1943 because of recurring paranoid delusions of persecution. After the war, he worked for the War Crimes Tribunal in Germany as a legal researcher but left his position in order to protest what he felt was the tribunal's unfair treatment of the Nazi leaders who were to be tried. Subsequently, in 1948, he moved to Ireland and produced his magnum opus. His passport was revoked in 1952 and there were accusations in 1954 that he was affiliated with neo-Nazis, but Yockey still traveled extensively, bringing word of his book to Egypt, Europe and Canada as well as the United States. Eventually arrested when it was found that he held three different passports, Yockey committed suicide with a cyanide pill while in prison. His last visitor was Willis Carto. ${ }^{38}$ Yockey was one of the first to lay down the tenets of Holocaust denial by claiming that Jews and other "Culture Distorters" were responsible for fabricating the Holocaust myth

\footnotetext{
${ }^{38}$ Deborah Lipstadt, Denying the Holocaust: The Growing Assault on Truth and Memory (New York: The Free Press, 1993), 146-147.
} 
and creating the propaganda to support the hoax. Relying more heavily on classic antisemitic themes than later denial tracts, Yockey's book was re-released in 1962 by the Noontide Press with an introduction by Carto. Stimely was fascinated by Yockey and made reference to his respect for the writer in many of the letters that appear in the collection. In a July 1978 note, Stimely wrote to Maurice William Palmer, the President of the American National Socialist Party, that Imperium was "a magnificent Neo-Nazi book indeed, and one that could (and was meant to) serve quite a useful purpose." 39

Later, in an August 1980 letter to Samuel Edward Konkin III of the New Libertarian, Stimely wrote, "I must tell you, Sam, that I am a Revisionist first, a Yockeyite neo-fascist second, and a libertarian (and this only in a 'fellow-traveller' sense) third." 40

Following his graduation from the University of Oregon, Stimely served as a second lieutenant and Army artillery training officer at Fort Still, Oklahoma. He was eager to discuss his views with others and even wrote an article for the division newspaper, which carried the headline, "Eugene lieutenant offers alternative view of W.W.II history." ${ }^{41}$ By 1982, he had moved to Torrance, California, and was hired as the assistant director of the IHR, possibly as a result of his correspondence with Tom Marcellus, who

\footnotetext{
${ }^{39}$ Keith Stimely to Maurice William Palmer, 9 July 1978, Box 30, folder 3, Keith Stimely Collection.

${ }^{40}$ Keith Stimely to Samuel Edward Konkin III, 20 August 1980, Box 6, folder 2, Keith Stimely Collection.

${ }^{41}$ The Wolf Print, Box 15, folder 8, Keith Stimely Collection.
} 
had been promoted to the directorship after David McCalden's departure the previous year.

Letters between Marcellus and Stimely reveal a warm friendship with many shared interests. Marcellus, in a short note in January 1982, asked Stimely,

Have you ever chanced to listen to Ernst Bloch's

Concerto Grosso \#1? It's really delightful. And I liked it just as much even after I found out the guy was Jewish. Most of the other stuff, however, personifies that almost typical maudlin-Fiddler-on-the-Roof-lifeis-so-hard-for-us-poor-Jews mentality. We hold this truth to be self evident: The Jew is the architect of his own persecution.

God -- that's terrible. What's come over me? I used to be so sensitive and tolerant. ${ }^{42}$

Stimely's duties as assistant director included answering correspondence from IHR members and Journal readers, many of whom were involved in more overtly racist organizations. In July 1982, Stimely wrote to white supremacist David Duke inquiring about a possible publications exchange between the IHR and Duke's National Association for the Advancement of White People. ${ }^{43}$ This may have been the same year that Stimely received an undated Christmas card from Duke, signed with holiday cheer,

\footnotetext{
${ }^{42}$ Tom Marcellus to Keith Stimely, 21 January 1982, Box 1, folder 5, Keith Stimely Collection.

${ }^{43}$ Keith Stimely to David Duke, 19 July 1982, Box 2, folder 5, Keith Stimely Collection.
} 
"May you have a meaningful and merry Christmas... may they forever be White!"44 Stimely also speculated with a colleague about the consequences of Israel's 1982 invasion of Lebanon, not pausing to reflect on the irony of a white supremacist showing sympathy for Arab people of color, when he wrote in 1982, Paradoxically, the Zionists are making it easier for us. The Israeli invasion and a slaughter campaign in Lebanon has been, for those poor Mideasterners, a tragedy indeed; but it is waking up the world to Israeli/Zionist criminality. As always, the Jews prove to be their own worst enemies. I hope Menachem Begin stays in power a long time yet! ${ }^{45}$

In November 1983, Stimely was promoted to the editorship of the Journal of Historical Review. Less than a year later, on July 4 , his fears about the hostility of the outside world would be realized when a fire broke out at the IHR headquarters. Like the Reichstag fire of February 1933, it is possible that nobody will ever know for sure who really unleashed this conflagration. However, the IHR's newsletter referred to the blaze as a "holocaust," ${ }^{46}$ and declared that "trained terrorists, members of the Israeli army, were flown into New York and Los Angeles," used "a military flame repellent (probably supplied from the U.S. as military aid, courtesy of U.S. taxpayers)" and, after flaming the IHR

\footnotetext{
${ }^{44}$ Christmas Card from David Duke, Box 47, folder 8, Keith Stimely Collection.

${ }^{45}$ Keith Stimely to Frieder Bulach, 27 August 1982, Box 2, folder 5, Keith Stimely Collection.

${ }^{46}$ The IHR Newsletter, August 1985, Box 1, folder 2, Keith Stimely Collection.
} 
headquarters, "fled, returning to Israel, where we can presume they have resumed the routine of using their skills against Palestinian lives and property." The Jewish Defense League (JDL) of Meir Kahane was also implicated. "Government intelligence personnel" were listed as the source for this information ${ }^{47}$

Stimely claimed to have foreseen the problem when he wrote to a colleague, "I have always pestered Willis about getting... the hell out of L.A., and stressed this point particularly in a memo I wrote to him upon my leaving the area last Fall. Whether this latest incident will help make that point, I don't know." He concluded, "If [the Institute] is in L.A. -- or any such Jew- and Minority-infested urban area -- it should, I think, at least be ensconced high up in an office tower." ${ }^{48}$ To the consternation of other IHR members, Stimely had followed his own advice and decided to continue his editorship while living in Newfoundland, Pennsylvania.

Pressures from the outside world would, however, prove to be minor compared to problems within the denial community. With the assumption of editorial duties, Stimely increasingly came into contact with contributing members of the IHR like Arthur Butz and Robert Faurisson; the latter had attracted media attention in his native France because of the legal battles waged over his denial publications and the ensuing support he received from Noam

\footnotetext{
${ }^{47}$ The IHR Newsletter, January 1987, Box 1, folder 2, Keith Stimely Collection. ${ }^{48}$ Keith Stimely to Arthur Butz, 14 July 1984, Box 8, folder 1, Keith Stimely Collection.
} 
Chomsky, a renowned professor of linguistics at the Massachusetts Institute of Technology. The heightened responsibilities of Stimely's position were not easy for him. His short temper and habit of venting frustration by waging virtual wars of words through intense and vitriolic letter writing campaigns would eventually alienate him from the rest of the denial community. In these letters, the animosity that Stimely had previously directed at Jews and others targeted his own colleagues.

The first dispute of this kind concerned corrections the editor had made to an essay entitled, "Can an Administration Convict Itself?" submitted by Percy L. Greaves for the Pearl Harbor issue of the Journal in the winter of 1983-1984. In February 1984 Stimely sent Greaves a 12-page letter in which he countered Greaves' complaints and expostulated,

I have received the carbon of your letter to Tom [Marcellus] of 7 February. The slanders in that, reflecting your low, slinking character and, once again, your fundamental failure to comprehend what was laid out very clearly to you in December and even more clearly in January, deserve this reply, which will be my last communication with you. I hardly would have thought it possible, but once again I must take you by the hand like the child you evidently are, and reiterate what should have been simply understood by you so much earlier. 
Later, Stimely grew more violent:

I tell you that your writing/composition on this essay really stunk... If I ever hear you again telling anyone that I am a 'slap-together' kind of person who would produce any 'bastard' item, I will personally drive to Dobbs Ferry (it is not that far away) and bash your whimpering, simpering little face in. ${ }^{49}$

The most public and damaging dispute began in 1984, when Stimely objected to Charles Weber's translation (from German to English) of Wilhelm Stäglich's speech from the 1983 International Revisionist Conference, an address that was to be printed in the Spring 1984 issue of the Journal. ${ }^{50}$ Weber, a former professor of German at the University of Tulsa, served on the editorial advisory board of the Journal and also penned the pamphlet, The Holocaust: 120 Questions and Answers. What began as a dispute over Weber's minor errors of grammar rapidly deteriorated when both parties began duplicating the letters they sent to one another and mailing them to others in the denial community. In Stimely's opinion, Weber's occasional use of the double negative, as well as the awkward construction he used in several sentences, made the entire translation unusable, while Weber may have escalated the problem by being the first to share the details of their dispute and,

\footnotetext{
${ }^{49}$ Keith Stimely to Percy L. Greaves, 18 February 1984, Box 11, folder 3, Keith Stimely Collection.

${ }^{50}$ Wilhelm Stäglich, "Der Auschwitz Mythos: A Book and its Fate in the German Federal Republic," Journal of Historical Review, trans. Charles E. Weber, Spring 1984, Vol. 5, No. 1, 47-68.
} 
at the same time, trying to cast aspersion on Stimely's character. "The main issue," he wrote to a Christian Identity activist in Colorado, was Stimely's

absolutely nasty, arrogant behavior. I also feel that he has misappropriated the considerable power of his office for his own emotional objectives. The JHR needs an editor who is a real gentleman and a scholar and whose private life is above reproach. ${ }^{51}$

The following month, Weber echoed these sentiments when he confided in James J. Martin, a former crony of Harry Elmer Barnes who was known in denial circles as the "dean of revisionism," that "to my way of thinking, the editor of the JHR should have a graduate degree in history or foreign languages, be willing to live in the Los Angeles area and have a private life beyond reproach." 52 While Weber was careful to couch this and other correspondence in subtle and seemingly inoffensive language, his letters betray that he believed that Stimely was a homosexual and wanted others to take note of his behavior. The fact that Stimely had decided to live away from Torrance and edit the Journal from a distance only added to Weber's suspicions about his private life. Stimely, on the other hand, taunted Weber, That the issue is now forced into the open for the consideration of the wider public is your fault alone. I

\footnotetext{
${ }^{51}$ Charles Weber to Wayne Lutton 17 June 1984, Box 7, folder 4, Keith Stimely Collection.

${ }^{52}$ Charles Weber to James J. Martin, 26 July 1984, Box 8, folder 2, Keith Stimely Collection.
} 
expect you to remember this, when the humiliation begins to be felt... Remember it, when you hear the howls of derisive laughter in your sleep... You have really asked for it this time, Dr. Weber -- and believe me, this time you are going to get it. $^{53}$

Not one to be silenced, Weber evidently made contact with McCalden who, at this point, had become something of a pariah within denial circles. Weber described this alliance as purely a defensive measure in order to combat Stimely's aggressive attacks against his character. ${ }^{54}$ When he was eventually castigated for his behavior, Weber replied in November 1984:

The Zionist enemies must be jumping up and down with joy as a result of Stimely's nasty campaign of vilification against me... Since McCalden is undoubtedly going to get one or more other versions of this whole sorry mess, I fear that I am going to have to send him my side of things just in order to defend myself. ${ }^{55}$ Weber apparently believed that his squabble with Stimely was important enough to be noticed by Jews, the aggregate group he felt was responsible for his problems and was even then eagerly awaiting his downfall. Similarly, Weber blamed his dismissal from the University of Tulsa on the Jews. "The

\footnotetext{
${ }^{53}$ Keith Stimely to Charles Weber, 7 May 1984, Box 7, folder 4, Keith Stimely Collection.

${ }^{54}$ Charles Weber to Wayne Lutton, 12 November 1984, Box 7, folder 5, Keith Stimely Collection.

${ }^{55}$ Charles Weber to Wayne Lutton, 20 November 1984, Box 7, folder 5, Keith Stimely Collection.
} 
Perpetual Aliens have virtually enslaved this country," he had complained to Stimely during a more friendly period. "I have suffered greatly at their hands." 56 Despite his alleged martyrdom at the hands of the enemy, Weber's alliance with McCalden would not be forgotten. In November 1984, Weber would be asked to leave the editorial advisory committee of the Journal. ${ }^{57}$ Later, in March 1986, Colorado Summit Ministries informed Weber that it had been discovered that McCalden was gay and Weber, tainted by association, would not be invited to speak before the organization as a guest lecturer. ${ }^{58}$

Now Tom Marcellus, sensitive to his responsibilities as IHR director, leaped into the fray. As early as April 1984, he had taken Stimely to task concerning his habit of writing inflammatory letters to perceived adversaries. "The right wing is aberrated enough," he scolded, "without adding to this with further harshness and crankyness." In addition, he warned:

There are several people who are alienated from you as a result of having had dealings with you. Among those are Butz, Weber, (Tom) Greaves and Brad Smith... One can never be accused of being stupid although he may certainly be. Much diplomacy must be employed

\footnotetext{
${ }^{56}$ Charles Weber to Keith Stimely, 3 April 1982, Box 8, folder 5, Keith Stimely Collection.

${ }^{57}$ Tom Marcellus to Wayne Lutton, 2 November 1984, Box 7, folder 5, Keith Stimely Collection.

${ }^{58}$ Wayne Lutton to Charles Weber, 31 March 1986, Box 7, folder 5, Keith Stimely Collection.
} 
by you in your position. It is part of the job description of "Editor." 59

Marcellus tried again to reach Stimely when he wrote, "Saw your wretched letter to C. Weber. God, Keith, Weber may be bothersome, but he ain't no fuckin' enemy. Ease up." ${ }^{60}$ However, with Stimely acting in a noncompliant manner, Marcellus eventually sent a letter to Weber that apologized for Stimely's behavior. He particularly criticized Stimely's habit of drawing caricatures or creating collages that ridiculed and demeaned his adversaries and were often mailed out to IHR colleagues.

Marcellus also pointed to Stimely's "usually long letters of criticsm [sic] and diatribe that he seems compelled to mail to most anyone who disagrees with him." ${ }^{61}$ Still, such criticism did not deter Stimely. In an October 1984 letter to Butz, he went on for ten pages about his perception of the problems with Weber, referring to his adversary as a "dope," "simple clown," "pathetic fool," miserable coward" and "slinking weasel." He also suggested that Weber had a low IQ and, lastly, that "Charles Weber is not only plain 'dumb,' but is in fact suffering from some sort of special neurological condition -- most likely early-stage Alzheimers [sic] Disease."62 Weber, of course, saw all of these insults when Wayne

\footnotetext{
${ }^{59}$ Tom Marcellus to Keith Stimely, 27 April 1984, Box 1, folder 5, Keith Stimely Collection.

${ }^{60}$ Tom Marcellus to Keith Stimely, 25 May 1984, Box 1, folder 5, Keith Stimely Collection.

${ }^{61}$ Tom Marcellus to Charles Weber, 22 June 1984, Box 8, folder 5, Keith Stimely Collection.

${ }^{62}$ Keith Stimely to Arthur Butz, 9 October 1984, Box 8, folder 1, Keith Stimely Collection.
} 
Lutton, who worked for Colorado Summit Ministries, sent him a copy of Stimely's letter to Butz that Stimely, obviously, had seen fit to mail to Lutton. ${ }^{63}$

Mark Weber, the co-director of another denial organization called the "Committee on Open Debate on the Holocaust" and a contributing member of the IHR, had also obtained a copy of the October letter. He sent his opinion to Stimely days later:

Your written slings against $\mathrm{Ch}$. Weber (and anyone, for that matter) will be more effective in the long run if you stick firmly to the facts. No matter how internally satisfying it may be, it hurts your effectiveness when you write about Alzheimer's disease or use extremely loaded adjectives for the sake of effect. ${ }^{64}$

Stimely's definitive statement on the imbroglio, though, was a 44-page "White Paper" that meticulously reproduced his entire argument against Weber. Fourteen pages were devoted to examples of the problems Stimely saw with Weber's translation, with comments such as, "I called up Mortimer Snerd and even he thought there was something wrong with this sentence." Fifteen pages listed direct quotations from others who had been pulled into the conflict and had demonstrated support for Stimely's side of the argument. The last page was a graphically drawn caricature of Weber, presumably executed by Stimely. The polemic mocked

\footnotetext{
${ }^{63}$ Charles Weber to Wayne Lutton, 19 October 1984, Box 7, folder 5, Keith Stimely Collection.

${ }^{64}$ Mark Weber to Keith Stimely, 18 October 1984, Box 8, folder 2, Keith Stimely Collection.
} 
the overly-pompous language Weber was fond of using. For instance, because Weber was inordinately proud of a pamphlet he had produced and would only refer to it as "his little propadeutic booklet," Stimely referred to his own White Paper, too, as "propadeutic." In addition, Stimely warned that Weber would regret the public fight he had picked because "the poor, dumb fucker just never realized until too late just who he was dealing with." 65

At roughly the same time, Revilo P. Oliver was getting fed up with the whole affair. Oliver, an older member of the Journal's editorial advisory board, was a retired professor of classics from the University of Illinois who had been active in right-wing extremist causes for four decades. ${ }^{66}$ In November 1984, Oliver sent out a letter to members of the Journal's editorial advisory board and key contributors. "I am dismayed by the hurricane in a goldfish bowl that has been raging since last Spring, ostensibly over certain translations from German." reported Oliver. Declining to take sides, the former professor acknowledged that, indeed, the quality of the Journal had improved since Stimely assumed the editorship. He also found no substantive problem with Weber's treatment of Stäglich's speech. ${ }^{67}$

\footnotetext{
${ }^{65}$ Keith Stimely, White Paper, undated, Box 8 , folder 4 , Keith Stimely Collection.

${ }^{66}$ Anti-Defamation League, Hitler's Apologists: The Anti-Semitic Propaganda of Holocaust "Revisionism" (New York: Anti-Defamation League, 1993), 72. ${ }^{67}$ Revilo P. Oliver, 3 November 1984, Box 7, folder 5, Keith Stimely Collection.
} 
Oliver concluded that the entire argument, "a series of polemics that border on irrationality," could be traced back to two factors. First, higher education had been co-opted and bastardized by Judeo-Communists and, thus, younger graduates of universities had been woefully undereducated, especially in the area of foreign languages. This was undoubtedly a jab at Stimely's lack of facility with German. Fortunately, Oliver gloated, men of his generation had been educated at a time when this "swindle" was not in place. Second, in reference to the coded allegations of homosexuality that were repeated in Weber's letters, Oliver reminded his readers that they were a race living in the ruined aftermath of civilization. Having been led astray by the illogical moral dictates of the capricious higher being created by Christianity, now largely abandoned, "the remnants of our enfeebled instincts were narcotized by the Liberal ideal of terrestrial bliss: a world of mindless mongrels, equal in proletarian squalor, and as happy as well-fed rats in perpetual rut." Out of this moral morass, Oliver contended, homosexuality was an unfortunate conclusion. ${ }^{68}$

All of these petty considerations, Oliver warned, were nothing compared to the real problem: that of the Jews and their control of the country. Oliver ended his letter with his conception of "the shadow of Things to Come," contained in his own perception of the Jewish holiday of Purim:

${ }^{68}$ Ibid. 
I need not now try to enumerate the many indications of the Jews' increasing confidence that they now have securely by the neck the stupid race they despise and have always hated. Their purposes are clearly shown in their myth of Esther, even in the much toned-down and attenuated version of it in the Jew-book that Christians revere and presumably approve. It is a fiction about a clever Jewess who exploited the sexual appetites of a feeble-minded Aryan monarch whom she secretly loathed and obtained from him legal authorization for Jews to kill on sight Aryans who did not cringe before the Holy Race that Yahweh specially created to rule over the lower animals in the world he deeded to them by the famous Covenant (B'rith). Their annual festival of Purim celebrates, not a tale about what never happened in the past but a plan for the future, and they will not rest until Purim has been made a national holiday and Jews or their shabbat goyim butcher in the streets every Aryan cur who, at the sight of a Jew, does not drop to his knees and knock his head three times on the pavement in veneration of his God-given Masters. So, my doughty Aryan friends, have a good time pulling each other's hair as you await your future. ${ }^{69}$

${ }^{69}$ Ibid. 
While accounting for the fact that the collection was compiled by Stimely and could have been carefully edited, it appears that a good percentage of those who involved themselves in the dispute agreed with Stimely that Weber was a pompous buffoon. However, Friedrich P. Berg was one member of the editorial advisory board who sided with Weber. Stimely apparently had made changes to Berg's article, "The Diesel Gas Chambers: Myth Within a Myth," a treatise on the improbable nature of the Nazis having used mobile gas vans to exterminate Jews and other prisoners. The crux of the problem was that Stimely had replaced the words "hundreds of thousands of drivers" with "many thousands" in reference to individuals who drove what Berg referred to as "gaswagons." 70

For Berg, Stimely's arbitrary editing was infuriating and completely inexcusable. The term, "many thousands" was, he believed, ambiguous, and diminished the power and force of his arguments. "The childish logic that Keith used to rationalize his brazen editing would be laughable if the consequences were not so serious," he complained to Marcellus. "How can I possibly bring myself to submit any material to you for publication ever again?... On the basis of my own experience, it seems that at least some of Charles Weber's recent criticisms of Keith have great merit." ${ }^{71}$

\footnotetext{
${ }^{70}$ Friedrich P. Berg, "The Diesel Gas Chambers: Myth Within A Myth," Journal of Historical Review. Spring 1984, Vol. 5, No. 1, 15-46.

${ }^{71}$ Friedrich Berg to Tom Marcellus, 15 June 1984, Box 9, folder 3, Keith Stimely Collection.
} 
Stimely's final confrontation involved IHR founder Willis Carto, whose tight grip on the daily affairs of the IHR and the Journal irritated and frustrated the young editor. Carto urged Stimely to include more articles in the Journal that did not pertain to World War II, arguing that the general public would more easily accept the IHR's contentions about the Holocaust if they were combined with information on other historical topics. In addition, a wider focus would make the group less likely to be attacked as neo-Nazi. ${ }^{72}$ As Stimely increasingly came under attack for his editorial decisions from other quarters, though, his resentment at Carto's meddling grew.

Additionally, Carto's conspiracy theories seemed ridiculous to Stimely. In November 1984, Carto had sent Stimely a letter which reviled "the British, using their typically Jewish wiles," and explained,

"Britain" is a totally different entity than Anglo-Saxon, which is English. "Great Britain" means primarily the banks which control the corrupt government, with the assistance of the Jews and the Welsh plus gobs of promonarchial [sic] propaganda for the suckers so they will keep supporting the criminal British ruling caste. ${ }^{73}$ Finally, when Carto deleted sections of a pending article by Robert Faurisson, entitled "A Challenge to David Irving," Stimely

\footnotetext{
${ }^{72}$ Willis Carto to Keith Stimely, 23 November 1984 and from Carto to Tom Marcellus, 27 January 1984, Box 2, folder 1, Keith Stimely Collection.

${ }^{73}$ Willis Carto to Keith Stimely, 23 November 1984, Box 2, folder 1, Keith Stimely Collection.
} 
exploded. On February 25, 1985, the beleaguered editor announced his resignation in a twelve-page denunciation, mailed out to all "editorial advisors, contributors to, and friends of the Journal of Historical Review," that specifically attacked Carto for practicing censorship and included the deleted sections of the Faurisson article. He mocked Carto's Welsh-Jewish conspiracy theory and took Carto to task for "butchering" the Faurisson article and shifting the responsibility for the result to Stimely. He complained that Carto was strangling the IHR because "the power he exercises over it is absolute, total, and all-pervasive, permeating every aspect of the organization's operations." Stimely also predicted that the Journal would soon be no more than a copy of the Liberty Lobby's publication, The Spotlight, "filled with rightwing-boobish about conspiracies and secret societies, that Willis Carto always wanted to make it." ${ }^{74} \mathrm{He}$ mailed this document of resignation, complete with a collage, to his friends and colleagues. The collage included a mock reference to Charles Weber's weight, a picture of Willis Carto labeled "Aaron Stein" and references to McCalden's repressed homosexuality.

Still, removing himself from the daily workings of the IHR did not lessen Stimely's animosity toward his former colleagues. In a letter written in June 1985 , he warned a potential IHR employee, Ted O'Keefe, away from any association with the organization. About his former employer, Stimely volunteered, "Be

\footnotetext{
${ }^{74}$ Keith Stimely, Letter of resignation, 25 February 1985, Box 2, folder 1, Keith Stimely Collection.
} 
prepared to be astonished at Carto's ignorance of history in general... he has absolutely no conception of 'objective' truth, of hard facts as immutable and not to be tampered with or rationalized away." He also indicated his weariness with the IHR as an organization when he wrote,

I can, in any case, get whatever information about the IHR's doings from others than yourself, very easily and very quickly, if I so desire. (I don't really: being closely involved for almost 3 years made me bored and tired of it all -- I mean the 'right wing' generally. Time for other things -- rather more normal, I'm not ashamed to say. ${ }^{75}$

Despite this show of bravado, Stimely was suffering from his designation as persona non grata in denial circles. $\mathrm{He}$ acknowledged as much in a letter to a colleague when he confided that Arthur Butz had been maligning him since he left the IHR. "He may slander on as much as he wishes," Stimely declared, for his notion that I give a twit what he thinks is just his own delusionary presumption. It is just rather sad that a man can't make it through the difficult and trying years of male menopause without making a spectacle of himself via the word-processor and the mails. $^{76}$

\footnotetext{
${ }^{75}$ Keith Stimely to Theodore O'Keefe, 15 June 1985, Box 2, folder 5, Keith Stimely Collection.

${ }^{76}$ Keith Stimely to Dr. Robert John, 17 August 1985, Box 2, folder 4, Keith Stimely Collection.
} 
As late as March 1986, though, Stimely was still fuming about the Weber affair and his painful separation from the IHR. In an open letter entitled "Toward the Promotion and Greater Glory of Charlieismus: A Document of Shame," he sulked, "Marcellus, Carto, Marki Maus [Mark Weber], all of them -- what a gang of backstabbing, back-alley, jelley-backed creeps. They can have their fucking 'Movement' and their Charlies."77

Stimely's final letters pertaining to the IHR outlined two areas of tension within the movement. First and most apparent was the ongoing battle between two separate ideological wings within the organization. The Young Turks, including Marcellus, Mark Weber and Stimely, were not interested in overt antisemitic material and outlandish conspiracy claims made against Jews in their professional publications. These individuals preferred the writing style of Butz and Faurisson, the pseudo-scholarly, "fact"filled copy associated with academic publication, and attempted to distance themselves from old-line antisemitic polemicists such as Carto and Revilo Oliver. Marcellus expressed this thought when he wrote that although Oliver was "brilliant, he's also a down-beat sour-puss who's so overtly anti-Jewish that he could only do us more harm, from a PR point of view, than good." ${ }^{178}$

\footnotetext{
${ }^{77}$ Keith Stimely, 7 March 1986, Box 8, folder 5, Keith Stimely Collection. The portion of the quote in parentheses is Stimely's attempt to ridicule Mark Weber's letter to McCalden asking him to be more supportive of the IHR, despite his differences with Carto.

${ }^{78}$ Tom Marcellus to Keith Stimely, 17 January 1984, Box 1, folder 5, Keith Stimely Collection.
} 
A second area of tension within the organization stemmed from the paranoia and lack of trust inherent within the denial community, which made cordial personal and professional relationships within the movement extremely difficult. Because of his inability to interact in a sociable or professional manner with his colleagues, Stimely had no choice but to leave the IHR. Yet the documents in the Collection suggest that the hostility displayed by Stimely was not entirely unique and that personal problems and emotional exchanges between members of the denial community were fairly common.

In fact, David McCalden's troubles with his colleagues show some parallels with the tribulations that had befallen Stimely. When he first left the IHR, McCalden informed Stimely that he was on "polite terms" with Willis Carto. ${ }^{79}$ However, less than a year later, he alluded to his contempt for Carto when he intimated to Stimely that his former employer had stolen the text of the introduction to Yockey's Imperium from a review of the book written by Revilo P. Oliver. Soon after this, McCalden and Stimely would no longer be on polite terms. On a copy of McCalden's Revisionist Newsletter, a mailing notable for its devotion to Holocaust denial, Jew-baiting and attacks on Carto and the IHR, Stimely printed in the margins, "This psychopath [McCalden] is going to try and hurt a lot of people before he goes down." 80 In

\footnotetext{
${ }^{79}$ David McCalden to Keith Stimely, 18 September 1981, Box 7, folder 2, Keith Stimely Collection.

${ }^{80}$ Revisionist Newsletter, Issue 9, June 1982, Box 6, no folder, Keith Stimely Collection.
} 
another McCalden mass mailing, this one in support of a group called "Truth Missions," McCalden was quick to denigrate various members of the IHR and made reference to "The Gay-Nazi cult operated by ex-Assistant Director Keith Stimely." ${ }^{11}$

Mark Weber attempted to mediate between McCalden and the IHR, insisting that, despite its faults, the organization did good work. In August 1982, McCalden replied that the IHR was a corrupt organization and rebuked Weber when he wrote that "to do nothing -- as you advocate -- would mean that the corruption would just fester and eventually erupt, and thus destroy the whole movement. The Jews will not allow us a second chance." 82 This friendly relationship would also deteriorate; on a photocopy of a January 1983 letter from Mark Weber that McCalden would mail out to individuals on his "Revisionist Newsletter" mailing list, McCalden would type, "Do we detect a note of bitterness here?

Could it perhaps be that Webster is still smarting that I rejected his homosexual overtures, when he tried to seduce me at the Tulse Hill Nationalist Centre?"83

McCalden would produce similar allegations against many of his colleagues. A November 1984 letter written by H. Keith Thompson, an editorial advisor to the Journal, responded to McCalden's allegations that Thompson was gay and engaged in an

\footnotetext{
${ }^{81}$ David McCalden, undated, Box 7 , folder 1 , Keith Stimely Collection.

${ }^{82}$ David McCalden to Mark Weber, 5 August 1982, Box 7, folder 2, Keith Stimely Collection.

${ }^{83}$ David McCalden, on a letter from Mark Weber, 5 January 1983, Box 7, folder 3, Keith Stimely Collection.
} 
affair with Stimely. McCalden typed triumphantly in the margins of this letter,

HKT does not deny being a militant gay. All he says is that he has been impotent these past 15 years. That does not prevent him from being the 'recipient' of Keith Stimely's ardent favors... Since I am not a homosexual, I am unable to give a 'blow' by 'blow' account of GayNazi shenanigans... nor would I wish to. ${ }^{84}$

Still, McCalden did not appear to be finished with his personal smear campaign; according to Stimely, an anonymous publication entitled "Deguello Report" was also a McCalden creation. ${ }^{85}$ The Report claimed that all Deguello members had, at one time, been employees of government intelligence agencies from a number of nations; these individuals had created an alliance to combat the communist threat. According to the author of the document, "we can say it this way: communism has three faces. These faces are socialism, Judaism and homosexualism." Examples were given to show how each of these three faces, independently or in an intertwined fashion, were threatening the fabric of Western society. While supportive of organizations that espoused extreme nationalist or racist ideology, the Report was unhesitatingly derogatory toward those individuals involved in these movements; accusations of homosexuality were made about

\footnotetext{
${ }^{84}$ David McCalden, on a letter from H. Keith Thompson, 7 November 1984, Box 7, folder 3, Keith Stimely Collection.

${ }^{85}$ Keith Stimely to Laird Wilcox, 16 August 1982 , Box 50 folder 7, Keith Stimely Collection.
} 
George Lincoln Rockwell, the founder of the American Nazi Party, as well as David Duke, Francis Parker Yockey and Hermann Goering. Willis Carto was not labeled a homosexual but was accused of associating with them. ${ }^{86}$

Stimely would not hesitate to strike back at McCalden. In November 1984, at the height of his dispute with Weber, he sent a letter to his nemesis. Addressing the letter to "Sandra Ross," another of McCalden's pseudonyms, Stimely offered sarcastic congratulations to his rival for adding Charles Weber to the editorial board of one of his publications, noting that "it's always nice to see two people finally getting together who so eminently deserve each other." He also mocked certain of Weber's conceits, including his need for people to know that he held a doctorate, and intimated that feeding the corpulent Weber, who was staying at McCalden's home, would be a hideously expensive affair. Stimely even provided a sample list of the copious amounts of food needed for Weber's visit. His parting jab, though, was aimed solely at McCalden:

P.S. I do trust that you have taken Dr. Kiosk's [McCalden's playful name for himself] medical counsel and maintained faithful attendance at the South Bay Gay/Bi "Coming Out" Group Support Sessions held weekly at Kaiser Psychiatric. These sessions have, as you know, gained an international reputation as

86"Deguello Report", Box 34, folder 16, Keith Stimely Collection. 
participatory forums for helping long-time suppressive, latent cases face the truth about themselves with a minimum of guilt and adjustatory difficulty. Dr. Kiosk has, I know, mentioned to you in particular the seminars conducted by Professor Krankenspiel on "Facing the Mirror: The Obsessive 'Anti'-Homosexual and His Path to Self-Awareness and Self-Respect. ${ }^{187}$ Later, McCalden reported on Stimely's acrimonious departure from the IHR and his feud with Carto. In an "Open Letter to Revisionists," McCalden wrote that Carto had, "recruited Keith Stimely, a brainy but unstable homosexual, from Oregon as 'Assistant Director.' Although Stimely originally doted on Carto, as part of his Yockey fetish, he quickly became enlightened as to Carto's true nature, and resigned, in disgust..." ${ }^{18}$ Clearly, McCalden was pleased that his own acrimony for Carto had been at least partially vindicated.

One of the most creative examples of this type of written warfare was the poem that Stimely included in a letter to Samuel E. Konkin III, editor of the New Libertarian. Detailing in explicit fashion some of the alleged sexual activity of McCalden, Stimely related: "Now Ulster [McCalden] one night he got drunk/And went up to Keith (it took spunk)/And said with face red/'Will you with me to bed?'/Thus admitting the truth of his funk..." Later, after

\footnotetext{
${ }^{87}$ Keith Stimely to David McCalden, November 29, 1984, Box 7, folder 2, Keith Stimely Collection.

88"Open Letter to Revisionists," written by David McCalden, undated, Box 1, folder 4, Addendum to the Keith Stimely Collection.
} 
phrasing a rhyming rejection, the Keith of the poem admonishes McCalden, "Secondly, did Keith then continue/You've obviously got problems within you/You'll find no help here/To get over your fear/ And conquer that self-hate within you." 89

While the Collection focuses on the period between 1979 and 1986, the documents also supply evidence that there were precursors to this intragroup animosity that date back to the 1960s. Harry Elmer Barnes had once styled himself as mentor to David Leslie Hoggan, whose revisionist work, Der erzwungene Krieg: Die Ursachen und Urhaber des 2. Weltkriegs (The Imposed War: The Origins and Originators of World War II) was translated from English so it could be published in 1961 in Germany. The book was based on Hoggan's history dissertation at Harvard but had been radically changed. According to one of Hoggan's advisors, the original dissertation had been "no more than a solid, conscientious piece of work, critical of Polish and British policies in 1939, but not beyond what the evidence would tolerate." 90 The new book transferred all blame for the beginning of the war to the Poles and the British and, additionally, attempted to justify the German treatment of the Jews. Among other assertions, Hoggan claimed that German antisemitic measures had only been developed to counter the Poles efforts to expel their Jews into Germany. ${ }^{91}$

\footnotetext{
${ }^{89}$ Keith Stimely to Samuel Konkin III, 7 July 1985, Box 6, folder 2.

${ }^{90}$ Lucy S. Dawidowicz, Lies About the Holocaust. ed. Neal Kozodoy, What is the Use of Jewish History? (New York: Schocken Books, 1992), 86.

${ }^{91}$ Lipstadt, Denying the Holocaust, 71.
} 
A series of letters from 1964 to 1967 that were photocopied from the Harry Elmer Barnes collection at the University of Wyoming and placed in the Stimely Collection detail a gradual falling out between Hoggan and his mentor. While Barnes had originally championed the German publication of Hoggan's book, he would reverse his sentiments just a few years later. In a letter to a Mr. Roseman dated in July 1964, Barnes speculated about Hoggan's book, "One can fake and forge safely if one is on the popular side, but it is hardly fitting for one upholding the unpopular position on so controversial a subject as World War II. $" 92$

The relationship between Hoggan and Barnes would grow even more strained. Hoggan wrote to Devin A. Garrity, the founder of Devin-Adair Company, which published and disseminated denial literature, in April 1965, accusing Barnes of "mutilating" the American version of his book. ${ }^{93}$ Barnes saw a copy of this letter and dashed off a 15-page reply to Garrity that emphasized Hoggan's alleged mental problems and claimed that Barnes had "humbled himself" by trying "to do the work that is necessary to make [Hoggan's book] fit to be published in an American edition, namely to check the documentation and to eliminate the more flagrant examples of the Nazi party line in his interpretations." Later, in March 1967, Barnes wrote again to

\footnotetext{
${ }^{92}$ Harry Elmer Barnes to Mr. Roseman, 25 July 1964, Box 12, folder 1, Keith Stimely Collection.

${ }^{93}$ David Hoggan to Devin A. Garrity, 23 April 1965, Box 12, folder 1, Keith Stimely Collection.
} 
Roseman and called Hoggan a "tragic psychopath," whom Barnes was tired of trying to assist and rehabilitate..$^{94}$

We can only speculate as to the reasons why Stimely chose to include this (and only this) correspondence from the Barnes collection. Whatever the motive may have been, the letters provide evidence that internecine squabbles, animosity and lack of trust have characterized the movement since it inception. The pattern is always the same: a once trusted member of the group is estranged from one or more of his colleagues, causing a formerly friendly or professional relationship to deteriorate into name-calling and vicious allegations about the individual's personal life and habits, including mental instability, lack of scholarly qualifications and sexual orientation. The letters demonstrate that the venom previously reserved for Jews and other minorities is transferred to a colleague, who is now seen as an impediment to the future academic respectability of the entire denial movement. The injured colleague, reacting with equal venom, is convinced that he alone can champion the cause, occasionally even venturing out on his own to avoid further hindrance from the mainstream denial community. Once estranged from the community, too, there could be no turning back.

In the aftermath of the Weber affair, there would be more allegations of deviant or disreputable behavior within the

\footnotetext{
${ }^{94}$ Harry Elmer Barnes to Mr. Roseman, 24 March 1967, Box 12, folder 1, Keith Stimely Collection.
} 
community. At the Revisionist Conference of 1984, Hoggan would insinuate that James Martin had traded sex for grades during one of his many stints as a professor. Martin wrote a letter of complaint to Mark Weber, who responded in March 1985 that he gave the allegations no credence. When Stimely received a copy of Weber's response, he scribbled a reply on the bottom. "A typical Mark Weber jesuitical [sic] performance," he wrote, "the oily snake twists and slithers his way out, answering a question other than the one really asked." ${ }^{95}$

Paranoia ran rampant within the denial community as each member hoped that his conduct would be considered to be above reproach. Thomas Francis had been tangled up in the Weber affair because he was involved in translating Wilhelm Stäglich's Der Auschwitz Mythos and was called on by both Stimely and Weber to support their respective conclusions about Weber's translation. He wrote for reassurance about his own standing within the denial community to Revilo Oliver, who offered a marginally reassuring reply:

In your earlier letter, you wanted to know whether I consider you a homosexual. I do not and I have never suspected that you are, but I will tell you bluntly that if you do not wish others to suppose that you are, you should stop behaving like one. ${ }^{96}$

\footnotetext{
${ }^{95}$ Mark Weber to James Martin, 13 March 1985, Box 12, folder 1, Keith Stimely Collection.

${ }^{96}$ Revilo P. Oliver to Tom Francis, 13 March 1985, Box 7, folder 7, Keith Stimely Collection.
} 
Ironically, before the bitter infighting documented in the Collection had begun, a letter from a man in Chickamauga, Georgia had praised the staff of the IHR for bringing civilized discourse to the cause. "I want to thank you gentlemen for the wonderful job you are doing," he wrote proudly, "our enemy can not refer to you men as rednrcks [sic] running through the piney woods wrapped in bed sheets." 97 Still, while the atmosphere of discord that had pervaded the IHR might not have been readily apparent to Journal subscribers, there were clues that threatened to reveal the underlying tensions within the organization. A terse blurb in the March 1985 issue of the IHR newsletter informed readers that, "Keith Stimely has just resigned in an incoherent rage because we would not permit him to use the pages of the quarterly to make personal attacks on one of the world's leading revisionist historians."98 Signed only "(WAC)," the paragraph did not clarify the identity of the wronged historian. For Journal subscribers, then, Stimely would disappear permanently from the institutional life of the IHR following his resignation. However, his involvement with the cause of Holocaust denial would continue in his new life in Portland, Oregon.

\footnotetext{
${ }^{97}$ M.L. Fisher to Keith Stimely, 4 April 1984, Box 2, folder 4, Keith Stimely Collection.

${ }^{98}$ The IHR Newsletter, March 1985, Box 1, folder 2, Keith Stimely Collection.
} 
Chapter III: Life After the IHR

Keith Stimely's split with the IHR did not diminish his interest in historical topics. Although one of his former colleagues had boasted to Charles Weber that Stimely had received the "coveted" Schlossberg Fellowship at Yale University for graduate work in history, the former editor was not destined to return to the state where he had been born. ${ }^{99}$ His defection led him instead to Portland, Oregon, where he began taking classes toward a master's degree at Portland State University. Letters from the former colleagues with whom he still kept in contact urged him to finish his studies and advance toward doctoral work as soon as possible so as to lend the prestige of a higher degree to the Holocaust denial cause. In fact, a sample of some of the papers he wrote during this period reveal that, while still interested in topics pertaining to World War II and its aftermath, he turned away from writing specifically about the Holocaust. Still, even though he removed overt references to Jewish world domination from his work, Stimely maintained his devotion to conservatism and rightwing political thought.

During winter quarter 1987, Stimely produced one paper entitled, "Joe Must Not Go: Four Defenses of Joseph McCarthy, 1968-1986," and another "American Diplomats, Hitler's Ascendancy and the Mussolini Model, 1922-1933: A Study in

\footnotetext{
${ }^{99}$ Wayne Lutton to Charles Weber, 31 March 1986, Box 7, folder 5, Keith Stimely Collection, University of Oregon Special Collections Library, \#183.
} 
Underexploitation." The latter chided American administrations for ignoring the anti-communist nature of Hitler's government while embracing the same within Italian fascism. Eventually, Stimely made a visit to the office of history professor David Horowitz. Expressing interest in completing a lengthy research project or thesis, Stimely submitted a six-page bibliography entitled, "Intellectual and Political History -- Modern America and Europe." A brief note explained that the inclusion of items in no way spoke to Stimely's expertise in all subjects; merely that, "in the main these are directional guideposts for the future, not markers on a path already well-trod." Still, Stimely was not one for excessive modesty:

On the other hand, that I drew up the list in longhand in an hour at Hamburger Mary's -- that is, from memory, without recourse to notes or references of any kind (needing to check such, upon typing, only in a few cases for the exact spellings of names) -- speaks something for a basic familiarity with these concepts and their interaction with each other, and for the abiding quality of these interest. I.e.: I'm serious about this stuff. ${ }^{100}$

The proposed thesis never materialized and Stimely never received his degree. Letters to his close friend and colleague, James J. Martin, reveal that there was some problem at Portland

\footnotetext{
${ }^{100}$ Keith Stimely, "Academic Interest/Areas of Concentration/Areas of Planned Work," 15 September 1986. From the files of Dr. David Horowitz.
} 
State University and hint that he was denied financial assistance from graduate fellowships or stipends. Martin attempted to console his friend with the suggestion that the whole problem was the fault of excessive Jewish influence in universities. "I am appalled at what has transpired re you and PSU," he reassured the unhappy student. "I don't think the ikeys control the synagogue anywhere near as airtight as they control the school house."101

Although his formal academic life had proved to be disappointing, Stimely shared with a colleague in Belgium his desire to expand his historical knowledge. The aspiring intellectual also reiterated his disgust for Willis Carto, the Institute for Historical Review and much of the movement with which he had been involved. Stimely stressed his need to get away from the anti-Jewish obsessions of Holocaust denial in order to concentrate more fully on the problem of the decline of Western civilization. "There is indeed no greater danger to Western Civilization than that represented by America, this polyglot, immature, fantastic idiot's paradise," Stimely lamented:
As American Fascists, my friends and I have encountered no more frustrating phenomenon than having to deal with -- even being considered a 'part of' -- the world view of the standard American 'right,' a world-view which is composed of lies, myths bearing no relationship to reality, prejudice, grandiose

\footnotetext{
${ }^{101}$ James Martin to Keith Stimely, 27 May 1988, Box 2, folder 11, Addendum to the Keith Stimely Collection.
} 
narcissistic visions, and complete ignorance of the rest of the world (including Europe). 'Conservatism' in America has managed, as all else, to become a Jewish province, a vehicle for the propagation merely of economic formulae, and backward thinking, and (in the international sphere) regard for the status of Israel as the priority exceeding all others." 102

Stimely maintained that he was far more interested in pursuing studies in philosophical and political theory by concentrating on individuals like Francis Parker Yockey, Oswald Spengler, Giovanni Gentile, and George Santayana. He also expanded on his own theory that the existing world order within Western Civilization must be destroyed in order to save those portions of it that were still uncorrupted. Stressing that he was, "not anti-semitic in the traditional sense," he theorized that part of the problem was the rightward shift in Jewish politics:

The former liberal Jews have realized that their unprecedented foothold (stranglehold, really) in America is quite dependent on the preservation of American values and institutions, those which gave them so much power, and so they are now in the rush to 'conserve' these. I do not join them in this rush. It is another Jewish and philo-Jewish game. ${ }^{103}$

\footnotetext{
${ }^{102}$ Keith Stimely to Robert Steuckers, 31 December 1985, Box 2, folder 19, Addendum to the Keith Stimely Collection.

${ }^{103}$ Ibid.
} 
Stimely expanded on such themes in subsequent letters. "I will tell you a fact," he confided in May 1986, "There is not and never has been a real American fascism." He characterized Carto and others of the movement as, "money-grubbing reactionaries in charge of the scene," and concluded that, "such reactionaries and their institutional forums offer no real ideological home to the idealists; the latter are merely subsumed in and consumed by the monstrosity known as 'American right-wing patriotic hucksterism.'"104

While still at Portland State, Stimely endeavored to put together a testimonial volume or "Festschrift" for Martin. To do so, he was forced to come into contact with his old colleagues, including his nemesis, David McCalden. In February 1988, McCalden responded to Stimely's request for a letter in praise of Martin's accomplishments and, to prove that the enmity between himself and Stimely had not diminished, referred to a previous communication from Stimely with the admonition, "I object to the appellation, 'little closet-bi," since I am 6'2" -- taller than the American average and (at a guesstimate) a good 2" taller than yourself." ${ }^{105}$ Stimely quickly replied and warned McCalden, "If so much as one quotation, citation, veiled reference, hint, etc., of this correspondence appears in your newsletter, you can forget about

\footnotetext{
${ }^{104}$ Keith Stimely to Robert Steuckers, 11 May 1986, Box 2, folder 19, Addendum to the Keith Stimely Collection.

${ }^{105}$ David McCalden to Keith Stimely, 10 February 1988, Box 4, folder 1, Addendum to the Keith Stimely Collection.
} 
any future such [correspondence]." ${ }^{106}$ McCalden responded on February 18 that he would publish any piece of information whenever he chose to do so, causing Stimely to concede wearily on February 24 that he did care what McCalden did as long as the surprise for James Martin was not destroyed. "I admit to reckoning without your well-honed ability to quote out of context, mislead egregiously, and simply lie," Stimely confessed ruefully. ${ }^{107}$ Stimely also approached Mark Weber about submitting a testimonial letter. This series of correspondence was polite on both sides, with the letters written by Weber almost fawning in their content. Stimely, too, was overly courteous until the subject of the IHR and its employees came up. "By the way, [Ted] O'Keefe is definitely not invited to participate," he warned, referring to the individual who had eventually taken his place as editor of the Journal. In an earlier, friendlier time, Stimely had actually cautioned O'Keefe against Carto and employment at the IHR, much as McCalden had once cautioned him, but now he proclaimed, If it can be avoided I don't want him or anyone else at the IHR to know about [the Martin testimonial]. That man was personally rude and implicitly dismissive to me, when he had no cause (had, in fact, quite the opposite). So he can go fuck himself or, if he prefers, sit in a corner and masturbate over a copy of

\footnotetext{
${ }^{106}$ Keith Stimely to David McCalden, 13 February 1988, Box 4, folder 1, Addendum to the Keith Stimely Collection.

${ }^{107}$ Keith Stimely to David McCalden, 24 February 1988, Box 4, folder 1, Addendum to the Keith Stimely Collection.
} 
ORIENTAL YUM-YUM GIRLS. (To think that this guy once had the nerve to deplore my alleged "morals." What a stinking hypocrite. $)^{108}$

Although the tribute to Martin appeared to languish, Stimely continued to stay in contact with other colleagues. Echoes of the earlier conflict with Carto over the Faurisson article reverberated when Stimely sent in the unexpurgated piece for publication in the New Libertarian. Samuel Konkin III, the editor of the periodical, wrote to Stimely to let him know that Carto had continued the spat by sponsoring a piece that enlisted Faurisson to agree to the fact that the reprinted article had been published without the author's consent and also alleged that Stimely had made the decision to delete segments from the original piece. Stimely responded by creating a letter addressed to all magazine subscribers that asserted,

It thus appears that the notorious liar, Willis A. Carto, either himself or through his lackeys, has been spreading falsehoods about me in the pages of the NL... I plan to publish my response to these garbage lies in a future NL... I will not let Carto get away with lies about this episode; I am past the point of caring generally about most of what he does to revisionism and the

\footnotetext{
${ }^{108}$ Keith Stimely to Mark Weber, 7 March 1988, Box 2, folder 10, Addendum to the Keith Stimely Collection.
} 
'right wing,' but I will not let him lie with impunity about this. ${ }^{109}$

Stimely made copies of a February 1988 note he had sent to Konkin to accompany the letter to subscribers. The earlier communication had declared that "if it is true that Carto or one of his lackeys actually accused me of 'deleting the [Faurisson] excerpt on [my] own,' then this is the goddamndest lie ever to appear in NL and I will shove it back in their faces."110

Another letter included in Stimely's files is curious in that it is provided in its entirety except for one omission; the salutation has been cut out, presumably to conceal the identity of the recipient. The letter, from one of Stimely's colleagues, Robert Lenski, asked frank and personal questions. "How old were you when you first realized you were gay?" Lenski queried. ""Do you sometimes feel real hatred for the female sex as a whole or hatred for your future as a gay or both?" Some of the questions are tantalizing because they appear to make important connections, as when the author asked if it was "harder emotionally to be a really dedicated racialist or a homo in America in the 1980s," and whether or not a "homo" could feel "any genuine solidarity" with "racial minorities." However, the possibility for any sort of empathy for others disappeared when the author inquired

\footnotetext{
${ }^{109}$ Keith Stimely to New Libertarian subscribers, undated, Box 2, folder 9, Addendum to the Keith Stimely Collection.

${ }^{110}$ Keith Stimely to Samuel Konkin III, 12 February 1988, Box 2, folder 9, Addendum to the Keith Stimely Collection.
} 
whether or not there were differences between white gays and gays who were also Jews or people of color. ${ }^{111}$

Stimely busied himself with other projects in the late 1980s, including the creation of a desktop publishing business called "UniverCity WorDesign." One of his first projects was to be a book on the trial of Ernst Zundel, a Holocaust denier whose legal battles over the publication and dissemination of denial literature made headlines in his native Canada. Lenski acted as the go-between for the two, but personal conflicts with Stimely erupted and made his job increasingly difficult. Stimely's first correspondence was friendly, and his quote for the project even included an "antiZionist discount" of $\$ 542 .{ }^{112}$ Not too much later, though, the disgruntled publisher was communicating directly with Zundel and complaining that Lenski "has been unable to extricate himself emotionally from the process of writing this book." Furthermore, Stimely alleged, Lenski had

gratuitously inserted himself emotionally into the process of designing and typesetting it, an insertion manifested in bizarre behavior... He has failed to grasp the elementary fact that, whatever may have been discussed between the two of you, I am not by written or verbal agreement working for him and never was, nor were we 'collaborating' in any way, and he has not

\footnotetext{
${ }^{111}$ Robert Lenski (presumably to Keith Stimely), 8 June 1985, Box 2, folder 9, Addendum to the Keith Stimely Collection.

${ }^{112}$ Keith Stimely to Robert Lenski, 2 January 1989, Box 1, folder 7, Addendum to the Keith Stimely Collection.
} 
been paying me therefore he is not going to call any design tune or any tune at all. ${ }^{113}$

Zundel begged Stimely to mend fences with Lenski. "It saddens me to see the infighting and breakdown of communication between Robert and yourself," he wrote. "I am caught in the middle, for I am depending on you both to help finish this project for the Cause." ${ }^{114}$ Subsequent pleas for Stimely's cooperation from both Zundel and Lenski appear to have gone unanswered.

While Stimely was distancing himself from more of his former friends and colleagues, he was making new contacts. One of his old acquaintances wrote in the hopes of introducing him to Adam Parfrey, whose New York publishing house, Amok Press, was characterized as "an apparently vital and by no means traditional 'right wing' reactionary group of the type we absolutely have to have if we are to get anywhere."115 After Parfrey moved to Portland in 1988, he and Stimely met at Quality Pies, a now defunct 24-hour greasy spoon diner, where the two began talking and eventually became friends. Parfrey, who founded Feral House Press in Portland, compiled the anthologies Apocalypse Culture and Cult Rapture, which documented the underground world of serial killers, neo-Nazis, Satanic cults and far-right Christian fundamentalists. The latter collection, explained Parfrey, delved

\footnotetext{
${ }^{113}$ Keith Stimely to Ernst Zundel, 7 August 1989, Box 1, folder 7, Addendum to the Keith Stimely Collection.

${ }^{114}$ Ernst Zundel to Keith Stimely, 2 September 1989, Box 1, folder 7, Addendum to the Keith Stimely Collection.

${ }^{115}$ William N. Grimstad to Keith Stimely, 7 September 1987, Box 2, folder 9, Addendum to the Keith Stimely Collection.
} 
into "the cultic experiences of groups you're going to wish you had never heard of." $\mathrm{He}$ continued:

How, why, did I sit with some of these characters long enough to not only obtain quotes, but glean their reptilian essence? Easy. My mind was on the payoff: thousands of people receiving an antidote to the Hallmark Card reality of America. Consider this book an emetic for the soul. ${ }^{116}$

Parfrey, perhaps disingenously, expressed surprise when contacted at the new Feral Press headquarters in Los Angeles at the fact that the Stimely Collection contained antisemitic expressions. Although Jewish himself, Parfrey claimed that antisemitism was never an issue in his relationship with Stimely. Yet Parfrey was aware of Stimely's association with the IHR and his belief in the importance of the writings of Francis Parker Yockey. In addition, although Parfrey was reluctant to admit that the sufferings of the Jews during World War II were in any way unique, he insisted that Stimely had never been allowed to work for him because he "did not want Feral House to be associated with Holocaust denial."117

Still, Stimely became increasingly involved in Parfrey's world, a distinct departure from the denial culture he had left in disgust. While the deniers' main goal was to arrive at academic

\footnotetext{
${ }^{116}$ Feral House Press Webpage [On-line]. Available: http://www.csn.net/central/feralhouse/apoc.html. ${ }^{117}$ Adam Parfrey, Oral Interview, September 1998.
} 
respectability, the individuals associated with Apocalypse Culture were on the fringe of American society and had no qualms about staying there. In 1991, Stimely wrote an article for a weekly Portland newspaper about Rex Diabolos Church, founder of the Portland-based Asylum of Satan, which he described as an "occultfascist, pro-ecology think tank... aimed at the natural human elite."118 Church was a protégé of Anton LaVey, who acquired some measure of celebrity in the 1960 s and $70 \mathrm{~s}$ as an advocate of Satanism; Parfrey published LaVey's book, The Satanic Witch, through Feral House Press.

Such interest in Satanic practices was not universally admired by those in Stimely's coterie. One of his correspondents, who signed all of his letters to Stimely, "Heil Hitler!" and instructed in each of them that all of his letters should be burned or otherwise destroyed, was supportive of the burgeoning Skinhead movement and predicted that "the Skinheads will become a substantial force if they are properly educated and receive sensible guidance from the likes of us." However, he feared the consequence of the Satanic influence within the movement: In the dualistic Semitic set-up, Xtianity [sic] and devil worship are two sides of the same Jewish coin, and a Satanist is still playing the Jew game even though he thinks he's not. The Skins have got to be informed that

\footnotetext{
${ }^{118}$ Keith Stimely, "Satan's Storm Trooper," Willamette Week. October 31November 6, 1991, Vol. 18, No. 1, 12.
} 
the real alternative, the only alternative, 2 judianity [sic], is Aryan heathenism/paganism, i.e. Odinism. ${ }^{119}$

Still, more and more of Stimely's associates seemed to share his enmity toward the mainstream denial movement. The correspondent who had written about the Skinhead movement opined that, "an alternate Revisionist institute needs to be established to reduce the disastrous effects of Carto," who was growing "more curmudgeonly and loony" all the time, and intimated that David Duke was equally difficult and was probably in cahoots with Carto. ${ }^{120}$

Stimely's involvement in alternative culture appeared to be growing. Despite Parfrey's current disavowals of any professional collaboration with the former editor, Stimely sent out a press release in the latter part of 1991 proclaiming that Parfrey and Feral House had signed with his public relations firm, touting himself as a "public relations counsel" and "agent for literary properties." ${ }^{121}$ Later, he wrote an article about Parfrey for PDXS, an alternative bi-weekly published in Portland. This article made reference to Parfrey's strident comments against feminism, including a diatribe against Andrea Dworkin, and his antipathy toward Steven Spielberg, who was represented as a closet

\footnotetext{
${ }^{119}$ Bob Williams to Keith Stimely, "Ember 20, 1988 (99)," Box 2, folder 9, Addendum to the Keith Stimely Collection.

${ }^{120}$ Bob Williams to Keith Stimely, "Merrymoon 291988 (99)," Box 2, folder 9, Addendum to the Keith Stimely Collection.

${ }^{121}$ Press Release from Keith Stimely Agency, "Adam Parfrey and 'Feral House' Sign With KS Agency," November 22, 1991. From the files of the Coalition for Human Dignity.
} 
pedophile. ${ }^{122}$ In the byline, Stimely billed himself as public relations representative for Feral House Press in the Pacific Northwest. However, according to Jim Redden, PDXS editor, Parfrey had called Redden after the article was published and complained that several of the quotes that Stimely had attributed to him were not accurate. ${ }^{123}$

Redden remembered that he met Stimely when the latter had offered assistance with a software program called Quark Xpress. Stimely had co-authored The Quark Xpress Book with David Blatner and volunteered to help Redden learn the program. The newspaper editor recalled that Stimely also helped him with background information for an article on Holocaust denial that was subsequently published in both PDXS and Hustler. Redden remembered that Stimely seemed quite ill at this time and became thinner and more wasted in appearance as time went on. Additionally, Stimely showed up at parties at Parfrey's house during the late 1980 s and early 1990 s where, although he was obviously ill and weak, he often attempted to pick fights with the other guests. ${ }^{124}$

Other than his penchant for writing personal letters, Stimely had not been a prolific writer during his employment at the IHR, and his time in Portland would be no different. Most of the editor's work at the IHR had consisted of cataloging the efforts of

\footnotetext{
${ }^{122}$ Keith Stimely, "Meet the Apocalypse Man: Quotations from Chairman Parfrey," PDXS. March 2, 1992, Vol. 1, No. 25, 3-4.

${ }^{123} \mathrm{Jim}$ Redden, Oral Interview, September 1998.

${ }^{124}$ Ibid.
} 
others in lengthy bibliographies or offering critical analysis of his colleagues through book reviews; his major Journal contribution was a bibliography pertaining to the work of the British fascist Oswald Mosely. ${ }^{125}$ Stimely's only published book-length works were the 1981 Revisionist Bibliography and his software manual. Yet he took it upon himself to organize a guide to the editorial notes, book reviews and other samples of his work under the title, Keith Stimely: Published Articles on History and Politics, 19751985. He also produced a thirteen-page inventory of all of the books in his own reference library. ${ }^{126}$ One of Stimely's bibliographies, compiled in 1979 , contained a note suggesting that the contents could help someone new to the study of the history of the second World War and that, "taken together, they provide grounds at the very least for a serious questioning of the standard 'holy' interpretation" of the "most well planned," war in history. ${ }^{127}$ Stimely never produced any substantive, original, scholarly works. For some reason, he preferred to play the role of a cataloguer of existing materials. The culmination of his need to document and organize was the donation of his personal papers, including IHR documents and correspondence, to the University of Oregon Special Collections Library in Eugene. Most of the Collection

\footnotetext{
${ }^{125}$ Keith Stimely, "A Bibliography of Works On and Relating to Oswald Mosely and British Fascism," Journal of Historical Review, Winter 1984, Vol. 5, Nos. 2,3 \& 4, 139-174.

${ }^{126}$ Keith Stimely, "Keith Stimely: Published Articles on History and Politics, 1975 - 1985," Box 15, folder 8, Keith Stimely Collection.

${ }^{127}$ Keith Stimely, Bibliography, 1979, Box 18, folder 1, Keith Stimely Collection.
} 
was made available to scholars in 1986 , but the final inventory was not completed until February 1991. The Library eagerly accepted Stimely's donation because it complemented its prior holdings from conservative politicians and activists.

In an inventory written to accompany the Collection, Stimely described the materials as a continuation of other archives "in the field of revisionist history," including Harry Elmer Barnes' personal papers at the University of Wyoming, and other materials housed at the Hoover Presidential Library in Iowa and the Hoover Institution at Stanford University. Stimely took pride in the fact that his collection highlighted World War II and "the 'Holocaust' controversy." Additionally, he wrote, "the 'inside' aspect of the collection makes it especially valuable to posterity as a record for researchers in historiography." ${ }^{128}$

Stimely's paper are organized into two distinct portions: "Revisionist History and Historiography," and "Neo-Fascist Movements." The first portion includes three sub-categories: "Institutional Files," "Subject Files -- Persons," and "Subject Files -Historical Issues." Much of the personal correspondence and material pertaining to the IHR is included in the first two subcategories. The third contains clippings from various periodicals, drafts of articles and unpublished manuscripts pertaining to subjects of interest ranging from "German cinema and music 193345," to "Pearl Harbor," to "Race and Intelligence." The second

\footnotetext{
${ }^{128}$ Keith Stimely, Inventory, February 1991, Box 1, folder 1, Keith Stimely Collection.
} 
portion of the papers is divided into two sub-categories, "Research Files -- Organizations \& Publications," and "Correspondences." All of the letters in the latter section have been sealed until thirtyfive years after the donation of the documents, but the publications section is open to researchers and is composed almost entirely of materials from white supremacist organizations such as the American National Socialist Party, the American Nazi Party, Aryan Nations, the Knights of the Ku Klux Klan, and the Larouche Organizations. Anti-Israel organizations and groups critical of the Jewish state, such as the Arab Information Center, American Alternatives to Zionism and Americans for Middle East Understanding, are represented in the Collection, as well as a few publications from the Anti-Defamation League of B'nai B'rith and the Klanwatch Project. ${ }^{129}$

Stimely's papers are surprising because of their large range. More than one hundred organizations are represented in the Collection and, while many of these groups, like the Klan or Aryan Nations, offer similar views about minority groups such as Jews and people of color, there are a few publications that offer subtle twists on the usual denial themes. For instance, the pamphlet of one group, entitled The Deep Backgrounder, greets new readers with the following message:

WELCOME! You are now in the world of THE DEEP BACKGROUNDER. This is a world to which, until now,

\footnotetext{
${ }^{129}$ Inventory to the Keith Stimely Collection, February 1991, Box 1, folder 1, Keith Stimely Collection.
} 
few people have been privy. It is a shadowy world, one that exists behind the everyday facades of what is today the world's most powerful city, Washington D.C. ${ }^{130}$

Articles in this newspaper disparage gay culture and emphasize how homosexuals are intimately connected with the power brokers of the capitol city.

A completely alternate view appears in NS Kampfruf, the publication of the National Socialist League. One newsletter, dated March-April 1974, claimed that the group was, "America's first and only homophile organization which is representative for the conservative and 'extreme right' members of the nation-wide 'gay' community."131 A letter from the Editor (identified only as "HWC") in April 1974, issued the following clarion call:

How long we've waited, we Aryan homophiles! How long we've waited for someone with strength and daring to wrench the wheel from those who've steered Gay Liberation hard to the Left... As a result, the straight world now pictures us with a pink Afro and a sequined tank-top, twitching to the demon beat of Darktown. Is that the measure of our heritage -- to

\footnotetext{
${ }^{130}$ The Deep Backgrounder, May/June 1982, Vol. 1, no 1, Box 34, folder 15, Keith Stimely Collection.

${ }^{131} N S$ Kampfruf, newsletter of National Socialist League, March/April 1974, Box 42, folder 8, Keith Stimely Collection.
} 
serve as ribbonclerks at the firesale of Western Civilization $?^{132}$

This publication would later become the N.S. Mobilizer and would lose its gay and male orientation. Membership would be open to "white persons" rather than exclusively to "white males."

Another mailing, produced on letterhead reading, "Star Fleet Command, Star Fleet Headquarters, United Federation of Planets," contained the following explanation: "The Star Fleet Armed Forces is an organization which is attempting to structure a future society along the Star Trek blueprint, which we feel depicts a viable and desirable alternative for the future." The reader was instructed that "although SFAF is generally for scientific advance within a spiritual Christian context, personal belief is respected"133 Articles in the accompanying newsletter "Intercom," included anti-Marxist and anti-Illuminati articles, advertisements for BB submachine guns, information on Holocaust denial and Star Trek quizzes which asked the reader, among other things, to name the state where Captain Kirk was born.

Besides compiling the documents and personal papers included in the Collection, Stimely continued with his sporadic freelance writing. In the last months of 1992, approximately a year after the final donation to the Collection, Stimely was working on an article for PDXS about Robert Heick, the leader of the White

\footnotetext{
${ }^{132}$ Letter from the Editor of NS Kampfruf, April 1, 1974, Box 42, folder 8, Keith Stimely Collection.

${ }^{133}$ Letter from the Editor of Intercom, Stardate 8312.20, Box 46, folder 11, Keith Stimely Collection.
} 
Workers Party. Redden claimed that the first part of the submission was well-written and provocative. The piece chronicled the dialogue that occurred at Heick's home in Southeast Portland when a group of white supremacists gathered to watch television coverage of the brutal riots that broke out in Los Angeles after the acquittal of the white police officers accused of beating African-American Rodney King. In the article, Stimely detailed how the group assembled to share their excitement over events that seemed to predict a future race war. "If they had given us every hour of prime time for two nights straight to broadcast anything we wanted, we couldn't have done any better than this," Heick exalted in the Stimely article. ${ }^{134}$ The remainder of the piece addressed Heick's views on topics ranging from "leftist" opposition from groups like the Coalition for Human Dignity to the circumstances surrounding the November 1988 death of Ethiopian Mulageta Seraw at the hands of three Skinheads, Kenneth Mieske, Steven Strasser and Kyle Brewster. The article was never published, though, because Redden felt that it deteriorated into incoherence and was virtually unusable. ${ }^{135}$ Perhaps the quality of the article was a reflection of the author's health. Redden observed that Stimely's once-sharp monologues appeared to have deteriorated into incoherent rambling by this time. In fact, the newspaper publisher claimed that he spoke with Stimely for the last time when he visited the

\footnotetext{
${ }^{134}$ Keith Stimely (undated). Untitled. Unpublished Manuscript.

${ }^{135} \mathrm{Jim}$ Redden, Oral Interview, September 1998.
} 
invalid's apartment to tell him that he could not use the article. Stimely countered this move by withdrawing his permission for the editor to print the Heick article that Redden had already decided not to print. Although his body was obviously ravaged, Stimely vehemently denied that there was anything physically wrong with him. Redden, however, had a different idea. "Everybody knew the guy had AIDS," he reflected in the summer of 1998. "I guess he considered himself one of the master race and didn't want to admit it." Parfrey, who supported the conclusion that Stimely suffered from the deadly disease, assumed that he had contracted it because of a part of his life that he had always tried to keep as a secret. "He was a closeted, sadomasochistic homosexual," Parfrey insisted. Redden was in agreement with this assessment. "He would come to Adam's parties with women," recalled Redden. "He would say they were his girlfriends, but nobody believed him." Redden also speculated that Stimely and Mark Weber had at one time been lovers, but admitted that this was not an assertion for which he had any proof but was more of "a feeling" that he had after spending time with Weber. ${ }^{136}$

Even in his earlier correspondence, Stimely had evinced an overt interest in issues of sexual orientation. The frantic gaybashing that was typical of his more vitriolic exchanges with McCalden, as well as his casual reference to compiling the document he gave to David Horowitz in Hamburger Mary's, at the

\footnotetext{
${ }^{136} \mathrm{Jim}$ Redden, Oral Interview, September 1998 and Adam Parfrey, Oral Interview, September 1998.
} 
time a well-known outpost of gay culture in Portland, were a few of the clues. In addition, he had shown a marked interest in Francis Parker Yockey's personal life, including the issue of whether or not Yockey had been a homosexual. In January 1982, Stimely received a note from David McCalden, who offered a peculiar confirmation of this supposition:

As for Yockey swinging both ways, I have no more evidence for this than I have for the 2nd World War taking place... But the bottom line is my own intuition which has been honed by work in show-business, rock'n'roll, cruise ships, San Francisco, and the restaurant trade. I have learned to spot a fag at 50 meters, mostly for reasons of self-preservation. ${ }^{137}$ Ironically, despite all reassurances to his subscribers that he was merely suffering from chronic fatigue syndrome, ${ }^{138} \mathrm{McC}$ alden would die in October 1990 from complications resulting from the AIDS virus. ${ }^{139}$

Continuing to defy his illness, Stimely remained active within his new social circle. One of his new cohorts was Boyd Rice, a musician who called himself "Non" to signify his rejection of establishment values. "The name implied everything and nothing,"

\footnotetext{
${ }^{137}$ David McCalden to Keith Stimely, 9 January 1982, Box 7, folder 2, Keith Stimely Collection.

${ }^{138}$ David McCalden Revisionist Newsletter, September 1990, Box 4, folder 1, Addendum to the Keith Stimely Collection.

${ }^{139}$ Anti-Defamation League, Hitler's Apologists: The Anti-Semitic Propaganda of Holocaust "Revisionism" (New York: Anti-Defamation League, 1993), 18.
} 
Rice explained. "It was a time when they were throwing the term 'anti-' onto everything. It seemed to be so reactionary, they seemed so tied to what they were against. I wanted to have something that implied the opposite of that." ${ }^{140}$ Rice also contributed to the Apocalypse Culture anthology, was associated with LaVey's Church of Satan and started the neo-Nazi Abraxas Foundation, which advocated "Social Darwinism," "Primal Law," "Resurgent Atavism," and Blood Mysticism." When Rice touted Non and the Abraxas Sound's "Total War Tour 1992," Stimely was listed as the piano player while Diabolos Rex provided the percussion. "Eurocentric and Not The Least Bit Shy About It," trumpeted the promotional flier for the tour. ${ }^{141}$

Perhaps the most incisive commentary on Stimely's life and his personal relationships until that point came from a student who wrote to Stimely for information on Holocaust denial, much as Stimely had once cast about looking for a peer group. "Why do you Revisionists intellectuals constantly toss the "fag" epithet back and forth?" the student wondered in one of his first letters. "Neither you nor David McCalden will rest in peace until you have photos of the other engaged in homosexual acts. My educated guess is that you both have Catholic tastes. But why do you air your dirty linen in public?"142

\footnotetext{
${ }^{140}$ Promotional flier for the Total War Tour 1992. From the files of Elinor Langer.

${ }^{141}$ Promotional Flier for Non and the Abraxas Sound's "Total War Tour." From the files of Elinor Langer.

${ }^{142}$ Jonathon Haynes to Keith Stimely, undated, Box 2, folder 9, Addendum to the Keith Stimely Collection.
} 
The student also acknowledged Carto's domineering tendencies but insisted on viewing him in a practical manner. "The old goat may be tough to work with but -- hey! It's still the only game in town," he scolded Stimely. "Neither you nor David McCalden can ever hope to match the influence of the IHR! I fail to see the justification for the interminable backstabbing squabbles. It's not advancing your cause." Finally, as a parting shot, the young correspondent expressed disdain for Stimely's new colleagues like Boyd Rice, who were denounced as "nihilist intellectual punk rockers" who were "talkers," and not "doers." Intimating that Stimely and his colleagues would never be a potent force in denial circles, the student added ominously, "I am more directed, more violent than them. Or you."143

As if in support of the student's denunciations, Stimely's condition continued to deteriorate. Parfrey remembered that his associate spent his last days in a hospice in Southeast Portland. Redden concurred, and recalled that Stimely had been placed with a gay, African-American roommate in the facility, an ironic ending for the life of the avowed racist and a situation that appeared to cause him a great deal of irritation. Shortly after his move to the hospice, Keith Bishop Stimely died on December 19, 1992. Parfrey claimed that Stimely's parents, who lived in Eugene, did not want many of their son's personal belongings. Stimely's mother gave Parfrey "some of his books on World War II and some S-and-M

${ }^{143}$ Ibid. 
gay clothes," which he later gave away or sold. Other than this, Stimely's death elicited little or no fanfare. No obituary was written for him in any of the major Oregon newspapers. ${ }^{144}$

${ }^{144} \mathrm{Jim}$ Redden, Oral Interview, September 1998 and Adam Parfrey, Oral Interview, September 1998. 
Conclusion

The legacy of the Stimely Collection is difficult to gauge, mainly because the mere presence of its documents can be seen as problematic. Writing on the dilemma to be found when confronting the issue of Holocaust denial literature in libraries, Kathleen Nietzke Wolkoff has acknowledged that repositories have usually chosen to either display denial literature to support the concept of intellectual liberty or censor the material because it is blatantly false and not supportive of the pursuit of knowledge. Wolkoff has also offered a third option in which Holocaust denial literature would be included in a library collection but clearly labeled inaccurate. ${ }^{145}$ The University of Oregon has chosen to display such material without caveat in the case of the Stimely papers, which are held in the well-regulated confines of the Special Collections Library and thus present a low risk in terms of inappropriate exposure. ${ }^{146}$

\footnotetext{
${ }^{145}$ Kathleen Nietzke Wolkoff, "The Problem of Holocaust Denial Literature in Libraries," Library Trends. Summer 1996, Vol. 45, No. 1, 87.

${ }^{146}$ There is, however, a much higher risk with books in the general library that are easily accessible to the general public. Here, Nietzke Wolkoff's position concerning labeling is much more applicable. Within the University of Oregon's computerized library catalog, it is possible to find "Holocaust Denial," "Holocaust Denial Literature," "Holocaust Denial Literature Bibliographies," and the general heading of "Holocaust 19391945" as subject headings. There are three entries under "Holocaust Denial": Deborah Lipstadt's Denying the Holocaust and two copies of Pierre VidalNaquet's Assassins of Memory, one in French and one in English. Two entries are included under "Holocaust Denial Literature": The Great Holocaust Trial by Michael A. Hoffman II and Worldwide Growth and Impact of "holocaust" Revisionism: A Handbook of Revisionist Views and the Controversy Today, published by the IHR; in addition, the handbook is crosslisted under "Holocaust Denial Literature Bibliographies." However, The
} 
Nevertheless, an examination of the motives behind the gift to the University can help in the ultimate assessment of the legacy of the Stimely Collection. Knowing that much of the material in his papers would not present the actions of the individuals involved in the movement in a favorable light, Stimely must have had specific reasons for collating these materials to present to the public. A former professor at the University of Oregon offered a hypothesis when he claimed that he had always foreseen the possibility of Stimely's eventual defection from the ranks. "On the one hand, I figured that he might turn out to be a subversive in the camp of the deniers," he reflected,

and this expectation was in a sense rewarded, for he did eventually fall out with Carto and the other movers in Torrance... On the other hand, I feared that because he was more intelligent and thoughtful than most of

Hoax of the Twentieth Century, clearly a piece of denial literature, has been categorized as part of the "Holocaust 1939-1945" subject heading. The peril of this situation is that Butz's tome has now been accorded the veneer of respectability because of its placement and categorization within the library. An inexperienced student perusing the catalog might decide to select Butz's book rather than a book by Raul Hilberg, Michael Marrus or any other credible Holocaust scholar, thus making denial his or her first exposure to literature about the Holocaust. From this first exposure, knowledge of the fact that the University has a significant collection donated by a Holocaust denier can only compound the original error by according even more legitimacy to the deniers; from this point, a quick look on the Internet, with its plethora of denial web sites, further reinforces the message that the Holocaust is not fact but merely one side of an ongoing argument. Yet another error is that Stimely's bibliography is listed, with five other entries, under "History , Modern -- 20th Century -- Bibliography" rather than solely in the denial section. The author has pointed out both errors to the $\mathrm{U}$ of $\mathrm{O}$ librarian and hopes that they will be rectified. 
them, he might prove more effective at purveying their message. ${ }^{147}$

The idea of Stimely acting as a subversive within the culture of denial can explain only a portion of his decision. Certainly, his personal papers support the fact that his devotion to the subject matter was genuine. Even after he had left the IHR, Stimely remained involved in the promotion of Holocaust denial, albeit through different channels than those available through the mainstream of denial culture. However, his support for the individuals within the movement was an entirely different matter because his affections for them were both fickle and fleeting. Perhaps this fact more than any other supports the conclusion that when Stimely presented the papers to the University in 1986, he did so as an act of revenge. Submitting these documents for public scrutiny was a more grandiose version of mailing out copies of his vengeful letters to his colleagues. Now, any scholar who was interested could read the documents that Stimely felt were proof of the superiority of his arguments.

Stimely's plan was almost foiled by his own untimely demise, however, as suggested by the original inventory he prepared for the Collection. The original inventory, written in 1986, is no longer available at the Special Collections Library. It is identical to the inventory, written in 1991, that currently resides within the Collection except for the fact that the original document made

\footnotetext{
${ }^{147}$ Roger Chickering (chickerr@ibm.net). (1998 August 28). Help with my thesis? E-mail to Linda Maizels (psu14560@odin.cc.pdx.edu).
} 
reference to material that was to be gradually added in the future. "Various personal, political, journalistic, musical, and historiographical papers as may in future be of interest to segments of scholardom," as well as Stimely's completed research on Francis Parker Yockey, were envisioned as part of the completed set of materials. ${ }^{148}$ However, most of those papers were not included in the final Collection, which spans the period between 1979 - 1986 and emphasizes Stimely's tenure at the IHR. But in January 1992, the former editor sent a letter to the Curator of the Special Collections Library that listed twenty-one additional file folders to be integrated into the Collection, including information on "K. Stimely Public Relations Agency, 1991," "K. Stimely Published Writings, 1989-1991," and "K. Stimely Graduate School Writings." Other files on David McCalden, Mark Weber and James J. Martin contained personal correspondence and other material from the years 1986 to $1991 .^{149}$ These documents were only recently discovered by the author; they had never been processed and had languished, unread, in the University archives since their donation in 1992.

This later attempt to include new material suggests that Stimely wanted to prove his devotion to the cause, devotion that transcended his involvement with the IHR. Even though several of these new files contained IHR newsletters and material concerning

\footnotetext{
${ }^{148}$ Keith Stimely, "Catalog Guide," 1986. From the files of Elinor Langer. ${ }^{149}$ Keith Stimely to J. Fraser Cocks, III, Curator, Special Collections, The Knight Library, University of Oregon, 30 January 1992. From the files of Elinor Langer.
} 
the organization, the primary emphasis was on Stimely's life and writings. The man who contributed mostly compilations, bibliographies and occasional news stories to the cause of Holocaust denial was advancing his expertise on the matter by presenting "the first significant public archival holding of revisionist history materials and the record of their controversies." ${ }^{150}$ As Stimely had always maintained in the context of his research and work on the Holocaust, the victors in any confrontation were the ones privileged to interpret history and shape it to their worldview, and he planned to present his version of the history of the movement in as definitive and authoritative a manner as possible. Rather than sabotaging the idea of Holocaust denial, Stimely meant only to attack his former colleagues, by showing that the movement's "controversies" had been no mere difference of opinion between himself and them. The papers of the Collection were intended to outline the contrast between Stimely's correct interpretation of events and his former colleagues' failure to comprehend the truth. Whatever Stimely's original intent may have been, however, the cumulative effect of the papers is that the curator looks just as harsh, cranky and vindictive as his colleagues. The legacy of the Collection becomes an inside look at the denial movement which highlights the

${ }^{150}$ Keith Stimely, Inventory for the Stimely Collection, February 1991, Box 1, folder 1, Keith Stimely Collection, University or Oregon Special Collections Library, \#183. 
absurdity of the competing contentions of Stimely, Carto, McCalden, and many other contributors to denial culture.

The distinction between differences of opinion and truths based on falsehood are as important to the question of the Collection as they are to the larger question of Holocaust denial. In both cases, the problem lies in the inability of Stimely and his colleagues to grasp the subtleties and complications of human nature and personal relationships. James Najarian has suggested that the deniers' emphasis on numerical data and obscure detail is the key to understanding their obstinate refusal to acknowledge the fact of the Holocaust. "Holocaust deniers cannot, at some level, read; they cannot understand a history of persons, only one of statistics," Najarian has emphasized..$^{151}$

In much the same way that the deniers cannot, in their misrepresentation of history, extrapolate that the masses of human beings murdered or tortured during the Holocaust were individuals, they often cannot, in their personal lives, create lasting human relationships with individual colleagues. In both their personal and professional existence, the deniers created immutable standards of truth and falsehood which allowed them to condemn those who disagreed with them to the ranks of the enemy. The petty squabbles about misspelled words and dangling participles, the crass name-calling and innuendo, and the continual search for a scapegoat found in the Stimely Collection mirror the tactics used

\footnotetext{
${ }^{151}$ James Najarian, "Gnawing at History: The Rhetoric of Holocaust Denial," The Midwest Quarterly, Vol. 39, Autumn 1997, 78.
} 
in place of legitimate dialogue concerning the Holocaust. Healthy human discourse and argument were replaced with irrational polemics that always placed blame on someone else, whether that individual was Jewish or gay or even a colleague who held a differing opinion.

There are those who maintain that the deniers knowingly engage in sophism. "The active deniers -- those who write books and articles, meet at conferences, translate each other's writings and quote each other -- know the terrible truth in full" Yisrael Gutman has insisted:

Their aim is simply to try and cover up the murder. I arrived at this conclusion when I scrutinized their work and found them taking things out of context, quoting half-sentences and carefully and deliberately avoiding information and reasoning that would trip them up and expose the lie. ${ }^{152}$

In accordance with this view, one of the deniers wrote to Stimely about his work on an IHR Special Report that had been released in February 1983. This individual criticized the more sensational aspects of the Report, such as hyperbolical language and punctuation used for ironic effect, and chided, "These are 'axe-grinding' characterizations, effective only in preaching to the faithful who are already convinced anyway. They don't win over a doubter. They make him suspicious." Later in the same letter,

\footnotetext{
${ }^{152}$ Yisrael Gutman, Denying the Holocaust (Jerusalem: The Institute of Contemporary Jewry, 1985), 20-21.
} 
he enthused, "That's why Arthur Butz is such dynamite. He's always understated and on a very high plane. And his facts are true." 153

In a world where there are both true and false facts, there are also many pitfalls. Years of suspicion and paranoia, of never knowing who might turn out to be in league with the enemy, would inevitably take their toll. In time, the anger and frustration from carrying such a burden of discontent might well be turned inward to further torment the individual in question. Keith Stimely was, according to those who came into contact with him, a closeted gay man who participated for years in professional and personal circles where his sexual orientation was regarded as a perverse abnormality. However, rather than recognizing a kinship with other traditionally persecuted individuals and groups, he chose to push away that aspect of his character and attempt to punish those around him. In the end, though, it is possible that he punished no one more than himself. The hatred that he directed first at Jews and later at his colleagues was at work in directing the shame and anger he felt at who he was.

The concept of universal animosity hiding behind more specific hatred is not new or unusual. However, it is within the Stimely Collection that one can see how universal this venom really is. Kenneth Stern has urged his readers to understand the ultimate danger of widespread hatred. "Jews make a mistake

${ }^{153}$ Eugene C. Brugger to Keith Stimely, 28 February 1983, Box 2, folder 5, Keith Stimely Collection. 
when they see anti-Semitism as something sui generis in human experience and combat it as such," Stern has warned:

It exists as a strain of a virus called human hate. By focusing on anti-Semitism alone, we ignore other strains of hate and allow them to grow. Anti-Semitism flourishes best in a climate of hate. Only by building institutions that confront all forms of hatred can antiSemitism be combated. ${ }^{154}$

The legacy of the Stimely Collection is its testimony to the truth of the universal nature of hatred. In the world of Holocaust deniers, where suspicion and animosity is encouraged, there is no one who can ever be exempt from this hatred, no one who will ever be immune from the effects of this deadly virus. Even for Keith Stimely, once a stalwart of the denial movement, the fact of his death was an unheralded event among his friends and colleagues. In the end, to borrow from the famous quote by Pastor Martin Niemöller, there was nobody left who was willing to speak for him.

${ }^{154}$ Kenneth Stern, Holocaust Denial (New York: The American Jewish Committee, 1993), 91-92. 


\section{Epilogue}

The IHR did not fall apart after the turbulent year when Stimely resigned. The editorial post at the Journal remained vacant from 1984 until 1986; probably both Mark Weber and Tom Marcellus took on this responsibility in addition to their other duties. Robert Berkel became the editor from 1986 through 1987, but from 1987-1988, the Journal went on a brief hiatus. Theodore J. O'Keefe, who Stimely had cautioned against taking the job, revived the periodical and kept it alive for the next four years; Mark Weber picked up the task in 1992 and still holds the position. ${ }^{155}$

In the early 1990s, a power struggle erupted at the IHR when Tom Marcellus and other IHR stalwarts staged a revolt against Willis Carto in order to try and sanitize the IHR's reputation and divorce it from Carto's more overt racist and antisemitic ideology. Carto, after being "forced out" of the IHR in 1993, filed a lawsuit to regain control of the Institute. ${ }^{156} \mathrm{He}$ lost this action and, in addition, a multi-million dollar judgment was leveled against him in 1996 for "illegally converting money left to the IHR." The funds in question, a number somewhere in the millions, had been bequeathed to the IHR by an heir of Thomas

\footnotetext{
${ }^{155}$ Insitute for Historical Review Webpage [Online]. Available: http://www.ihrorg/index.html.

${ }^{156}$ Lin Collette, "Encountering Holocaust Denial." Eyes Right! Challenging the Right Wing Backlash, ed. Chip Berlet. (Boston: South End Press, 1995), 225.
} 
Edison. Carto decided instead to start a new journal, the Barnes Review, that was to be his own paean to Holocaust denial. ${ }^{157}$

Stimely, it appears, had been correct in his earlier assessment of his former employer. The IHR staff made many of the same claims against Carto that Stimely had made ten years earlier. Arthur Butz offered his opinion that Carto had "sought to transform the Journal of Historical Review into a journal with a racialist, political mission and editorial content," a move that Butz predicted would have ruined the IHR. He added that "Willis Carto has now been added to IHR's list of powerful enemies," and dismissed Carto's claims that the Anti-Defamation League had taken over the IHR as "ludicrous." Meanwhile, Stimely has been at least partially exonerated by the IHR, where he is remembered as a "gifted young writer who was astonishingly well-read, as can be seen by the number of book reviews he wrote during his tenure [as editor of the Journal of Historical Review]"158

${ }^{157}$ Institute for Jewish Policy Webpage [Online]. Available: http://www.jpr.org.

${ }^{158}$ Institute for Historical Review Webpage [Online]. Available: http://www.ihrorg/index.html. 
Works Cited

Manuscripts

Stimely, Keith. Collection \#183. University of Oregon Special Collections Library, Eugene.

Stimely, Keith. Addendum to the Keith Stimely Collection.

Oral Interviews

Parfrey, Adam. September 1998.

Redden, Jim. September 1998.

Interviews by e-mail

Chickering, Roger (chickerr@ibm.net). (1998 August 28).

Help with my thesis? E-mail to Linda Maizels

(psu14560@odin.cc.pdx.edu)

Personal and Organizational Files

Coalition for Human Dignity

Horowitz, David

Langer, Elinor

Books and Articles

Anti-Defamation League. Hitler's Apologists: The AntiSemitic Propaganda of Holocaust "Revisionism." New York: AntiDefamation League, 1993. 
Berg, Friedrich P. "The Diesel Gas Chambers: Myth Within A Myth." Journal of Historical Review. Spring 1984, Vol. 5, No. 1.

Butz, Arthur A. The Hoax of the Twentieth Century.

Richmond, Surrey: Historical Review Press, 1974.

Collette, Lin. "Encountering Holocaust Denial." Eyes Right!

Challenging the Right Wing Backlash, ed. Chip Berlet. Boston:

South End Press, 1995.

Dawidowicz, Lucy S. Lies About the Holocaust, ed. Neal Kozodoy, What is the Use of Jewish History? New York: Schocken Books, 1992.

Finkielkraut, Alain. The Future of a Negation: Reflections on the Question of Genocide, trans. Mary Byrd Kelly. Lincoln: University of Nebraska Press, 1998.

Gutman, Yisrael. Denying the Holocaust. Jerusalem: The Institute of Contemporary Jewry, 1985.

Horowitz, David A. Beyond Left and Right: Insurgency and the Establishment. Chicago: University of Illinois Press, 1997.

Kornberg, Jacques. "The Paranoid Style: Analysis of a Holocaust-denial Text." Patterns of Prejudice. 1995, Vol. 29, Nos 2 and 3 .

Lipstadt, Deborah. Denying the Holocaust: The Growing Assault on Truth and Memory. New York: The Free Press, 1993.

Najarian, James. "Gnawing at History: The Rhetoric of Holocaust Denial." The Midwest Quarterly, Vol. 39, Autumn 1997. 
Stäglich, Wilhelm. "Der Auschwitz Mythos: A Book and its Fate in the German Federal Republic." Journal of Historical Review, trans. Charles E.Weber, Spring 1984, Vol. 5, No. 1.

Stern, Kenneth. Holocaust Denial. New York: The American Jewish Committee, 1993.

Stimely, Keith, ed., 1981 Revisionist Bibliography: A Select Bibliography of Revisionist Books Dealing with the Two World Wars and their Aftermaths. Torrance, Calif.: Institute for Historical Review, 1981.

Stimely, Keith. "A Bibliography of Works On and Relating to Oswald Mosely and British Fascism." Journal of Historical Review, Winter 1984, Vol. 5, Nos. 2, 3 \& 4.

Stimely, Keith. "Meet the Apocalypse Man: Quotations from Chairman Parfrey." PDXS, March 2, 1992, Vol. 1, No. 25.

Stimely, Keith. "Satan's Storm Trooper." Willamette Week, October 31-November 6, 1991, Vol. 18, No. 1.

Wolkoff, Kathleen Nietzke. "The Problem of Holocaust Denial Literature in Libraries." Library Trends, Summer 1996, Vol. 45, No. 1 .

Unpublished Works

Stimely, Keith. Untitled. Unpublished article for PDXS. 
Websites

Feral House Press Webpage [Online]. Available:

http://www.csn.net/central/feralhouse/apoc.html

Institute for Historical Review Webpage [Online]. Available: http://www.ihrorg/index/html.

Institute for Jewish Policy Webpage [Online]. Available: http://www.jpr.org 